\title{
Procedures for Use of, and Drill Cores and Cuttings Available for Study at, the Lithologic Core Storage Library, Idaho National Engineering Laboratory, Idaho
}

by Linda C. Davis, Steven R. Hannula, and Beverly Bowers

U.S. GEOLOGICAL SURVEY

Open-File Report 97-124

Prepared in cooperation with the

U.S. DEPARTMENT OF ENERGY

Idaho Falls, Idaho

March 1997

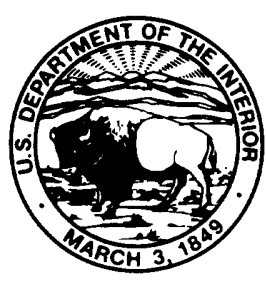




\section{U.S. DEPARTMENT OF THE INTERIOR}

BRUCE BABBITT, Secretary

\section{U.S. GEOLOGICAL SURVEY}

Gordon P. Eaton, Director

Any use of trade, product, or firm names in this publication is for descriptive purposes only and does not imply endorsement by the U.S. Government.

For additional information write to:

U.S. Geological Survey

INEL, MS 4148

P.O. Box 2230

Idaho Falls, ID 83403
Copies of this report can be purchased from:

U.S. Geological Survey

Information Services

Federal Center, Box 25286

Denver, CO 80225 


\section{CONTENTS}

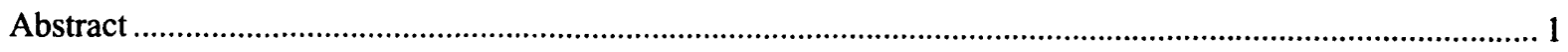

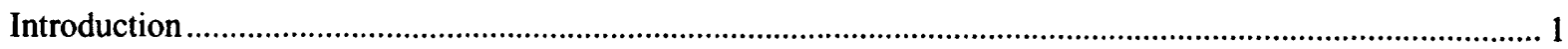

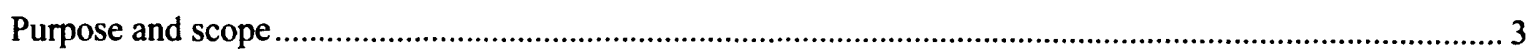

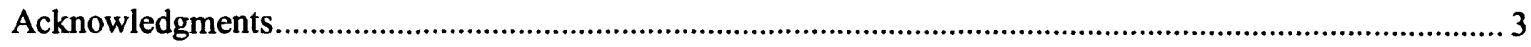

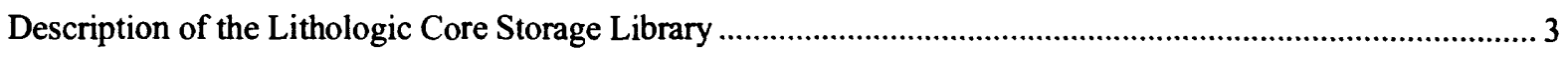

Procedures for use of the Lithologic Core Storage Library ................................................................................ 5

Drill cores and cuttings available at the Lithologic Core Storage Library ......................................................... 5

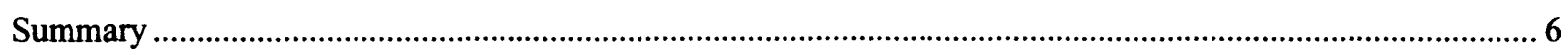

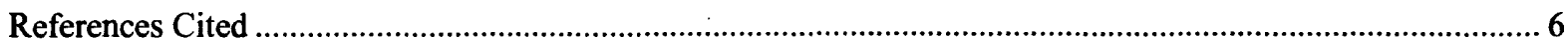

\section{FIGURES}

1. Map showing location of the Idaho National Engineering Laboratory and selected facilities......................... 2

2. Diagram of the Lithologic Core Storage Library floor plan ........................................................................ 4

\section{TABLE}

Table 1. Drill cores and cuttings available at the Lithologic Core Storage Library .7

\section{CONVERSION FACTORS}

\begin{tabular}{rll}
\hline Multiply & By & To Obtain \\
\hline inch (in.) & 25.4 & millimeter \\
foot (ft) & 0.3048 & meter \\
mile (mi) & 1.609 & kilometer \\
square foot ( $\left.\mathrm{ft}^{2}\right)$ & 0.09290 & square meter \\
square mile $\left(\mathrm{mi}^{2}\right)$ & 2.590 & square kilometer \\
\hline
\end{tabular}




\title{
Procedures for Use of, and Drill Cores and Cuttings Available for Study at, the Lithologic Core Storage Library, Idaho National Engineering Laboratory, Idaho
}

\author{
by Linda C. Davis, Steven R. Hannula, and Beverly Bowers
}

\section{Abstract}

In 1990, the U.S. Geological Survey, in cooperation with the U.S. Department of Energy, Idaho Operations Office, established the Lithologic Core Storage Library at the Idaho National Engineering Laboratory (INEL). The facility was established to consolidate, catalog, and permanently store nonradioactive drill cores and cuttings from investigations of the subsurface conducted at the INEL, and to provide a location for researchers to examine, sample, and test these materials.

The facility is open by appointment to researchers for examination, sampling, and testing of cores and cuttings. This report describes the facility and cores and cuttings stored at the facility. Descriptions of cores and cuttings include the well names, well locations, and depth intervals available. Most cores and cuttings stored at the facility were drilled at or near the INEL, on the eastern Snake River Plain; however, two cores drilled on the western Snake River Plain are stored for comparative studies. Basalt, rhyolite, sedimentary interbeds, and surficial sediments compose the majority of cores and cuttings, most of which are continuous from land surface to their total depth. The deepest core stored at the facility was drilled to 5,000 feet below land surface. This report describes procedures and researchers' responsibilities for access to the facility, and examination, sampling, and return of materials.

\section{INTRODUCTION}

The Idaho National Engineering Laboratory (INEL) occupies about $890 \mathrm{mi}^{2}$ of the eastern Snake River Plain in southeastern Idaho (fig. 1).
The INEL is managed by the U.S. Department of Energy (DOE) and operated by Lockheed Martin Idaho Technologies Company (LMITCO). INEL facilities are used for the development of peacetime nuclear-energy applications, nuclear-safety research, defense programs, and advanced energy investigations.

Since the 1950's, more than 500 test holes, auger holes, and wells have been drilled at the INEL to characterize hydrologic and geologic conditions in the subsurface, and to supply water to INEL facilities. Drill cores and cuttings from some of these holes and wells were stored in surplus buildings and other areas at the INEL, and at contractor facilities in Idaho Falls, Idaho, about $50 \mathrm{mi}$ east of the INEL. Before 1990, no attempt had been made to consolidate, catalog, or determine the spatial distribution and physical locations of cores and cuttings available for use by researchers. Also before 1990, many boxes containing cores were left out in the weather, rendering markings on the boxes unreadable and resulting in the loss of potentially valuable technical information for future investigations. This lack of organization resulted in duplication of work and added expense because additional cores were sometimes drilled to obtain information which may have been obtained from an existing core. In 1990, the INEL Lithologic Core Storage Library, hereafter referred to as the CSL, was established to consolidate, catalog, and permanently store nonradioactive drill cores and cuttings from investigations of the subsurface at the INEL, and to provide a location for researchers to examine, sample, and test these materials. The CSL is funded by the DOE and is operated by the U.S. Geological Survey (USGS), INEL Project Office. 


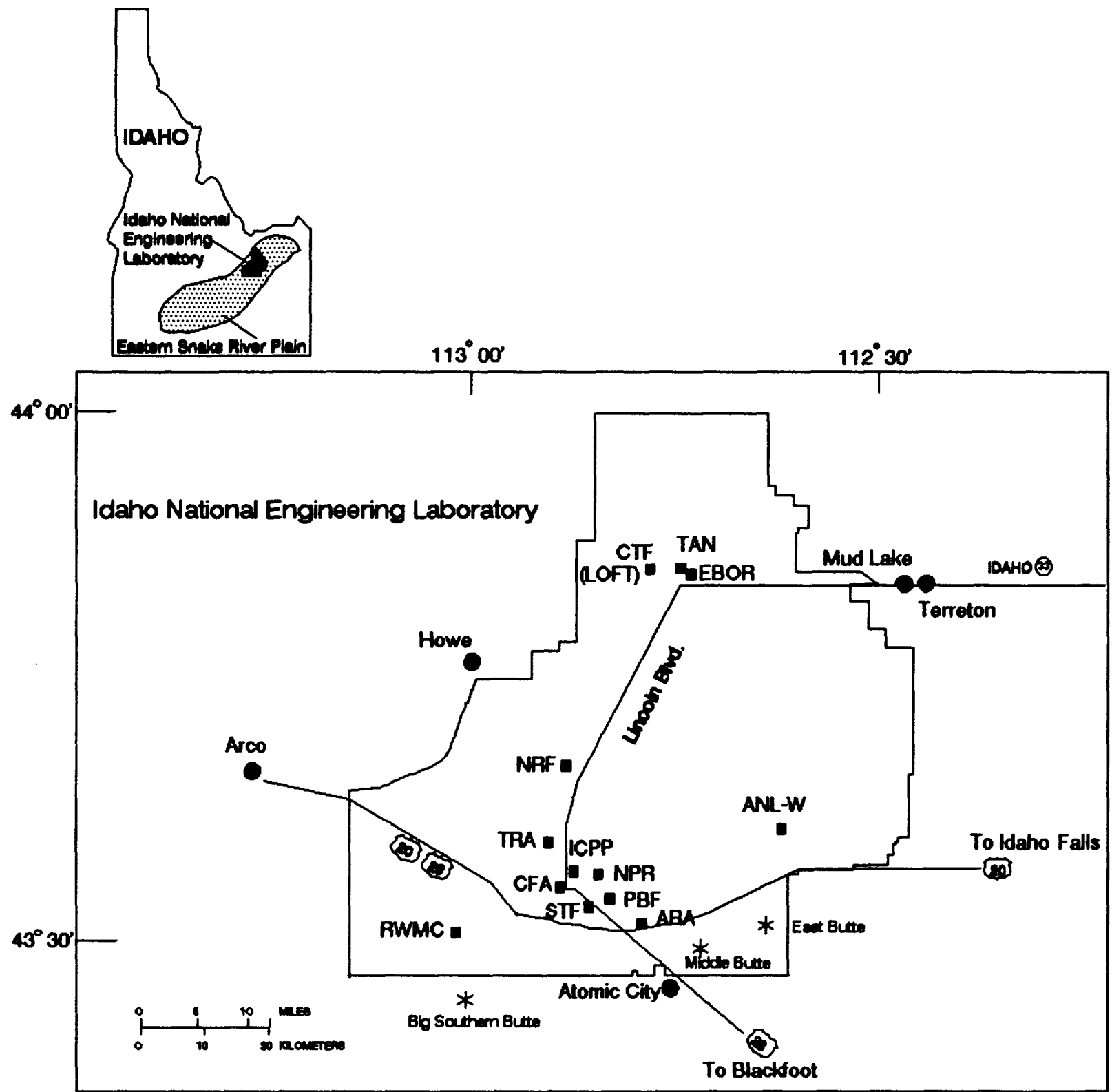

EXPLANATION

- Selected facilities at the Idaho National Engineering Laboratory

- Towns near the Idaho National Engineering Laboratory

\begin{tabular}{llll}
\hline ANL-W & Argonne National Laboratory-West & NPR & New Production Reactor \\
ARA & Auciliary Reactor Area & NRF & Naval Reactors Facility \\
CFA & Central Facilities Area & PBF & Power Burst Facility \\
CTF & Contained Test Facility formerty called & RWMC & Radioactive Waste Menagement Complex \\
& Loss-offluid Test Facility-LOFT) & STF & Security Training Facility \\
EBOR & Experimental Beryllium Oxide Reactor & TAN & Test Area North \\
ICPP & Idaho Chemical Processing Plant & TRA & Test Reactor Area
\end{tabular}

Figure 1. Location of the Idaho National Engineering Laboratory and selected facilities. 


\section{Purpose and Scope}

This report, prepared in cooperation with the DOE, describes the CSL, the procedures for use of the CSL, and provides a list of drill cores and cuttings currently (1996) stored at the CSL and available for study. In 1996, this list included about 50,000 $\mathrm{ft}$ of drill cores and several suites of drill cuttings (table 1). Most of the cores and cuttings were drilled at or near the INEL for studies of subsurface geohydrologic processes related to waste migration potential, geothermal potential, seismic potential, and characterization of the Snake River Plain aquifer. Basalt, rhyolite, and sediment compose the majority of these cores and cuttings. Two cores from the western Snake River Plain are also available for comparative studies. Petrographic thin sections, primarily from cores drilled at the Radioactive Waste Management Complex (RWMC) (fig. 1), may be examined at the CSL. This report does not provide results of analyses performed on many of these cores; however, some publications containing results are on file at the CSL. Anderson and others (1996) provide a list of data sources pertaining to many cores stored at the CSL.

\section{Acknowledgments}

The authors gratefully acknowledge the technical reviews of this manuscript by Steven $\mathrm{R}$. Anderson, USGS, Water Resources Division, and Duane E. Champion, USGS, Geologic Division. Their comments and suggestions greatly improved the quality and clarity of this report. Also, many employees of LMITCO, DOE, and Argonne National Laboratory-West provided information about the cores and cuttings stored at the CSL that completed or verified some of the information contained in this report.

\section{DESCRIPTION OF THE LITHOLOGIC CORE STORAGE LIBRARY}

The CSL is located at the Central Facilities Area (CFA) (fig. 1), Building CFA-663. It is a $6,163-\mathrm{ft}^{2}$ building consisting of $4,110 \mathrm{ft}^{2}$ of corestorage space, $1,340 \mathrm{ft}^{2}$ of laboratory space, which includes a rock room for sample preparation, $420 \mathrm{ft}^{2}$ of office space, a $143 \mathrm{ft}^{2}$ restroom, and a $150 \mathrm{ft}^{2}$ mechanical room for heating, cooling, plumbing, and electrical systems (fig. 2).

The core-storage area is equipped with metal racks on which pallets of cores and cuttings are stored. Most cores are packaged in waxed cardboard core boxes, each holding up to $10 \mathrm{ft}$ of core. Some cores are in 5-ft long wooden boxes that hold 15 to $20 \mathrm{ft}$ of core, depending on core diameter. A small forklift is used to move pallets of core on and off the racks. The core-storage area includes an examination/sampling area with several tables on which 300 to $400 \mathrm{ft}$ of core may be laid out at a time. Equipment available for use in the examination/sampling area includes a hydraulic core splitter, binocular microscope, petrographic microscope, hand lenses, and an assortment of hand tools. Photographic equipment, including a large-format camera, a 35-millimeter camera, copy stand, and accessories are also available for use, although users must provide their own film and developing services.

The laboratory at the CSL is used for examining, sampling, or testing cores and cuttings stored at the CSL. Laboratory equipment includes soildrying ovens, two oil-cooled rock saws, a drill press with coring bits $1 / 2$ to 1 in. in diameter, petrographic microscopes, a permeameter, balances, constant-temperature water baths, a mechanical sediment shaker and sieves, and an array of standard laboratory glassware and equipment. Chemicals must be provided by the users, and a Material Safety Data Sheet must be provided to CSL personnel for each chemical brought into the laboratory.

The office is a work area for CSL personnel to manage the database and records related to core availability, core loaned for study, and previous investigations conducted on the cores. Personnel at the CSL perform many functions related to the preservation of drill cores and cuttings for scientific investigations. Chain-of-custody records are maintained and procedures followed by CSL personnel for cores for which chain-of-custody procedures were initiated at the drill site. Additionally, CSL personnel research existing information about stored cores and cuttings, and maintain core-availability data. Some publications 


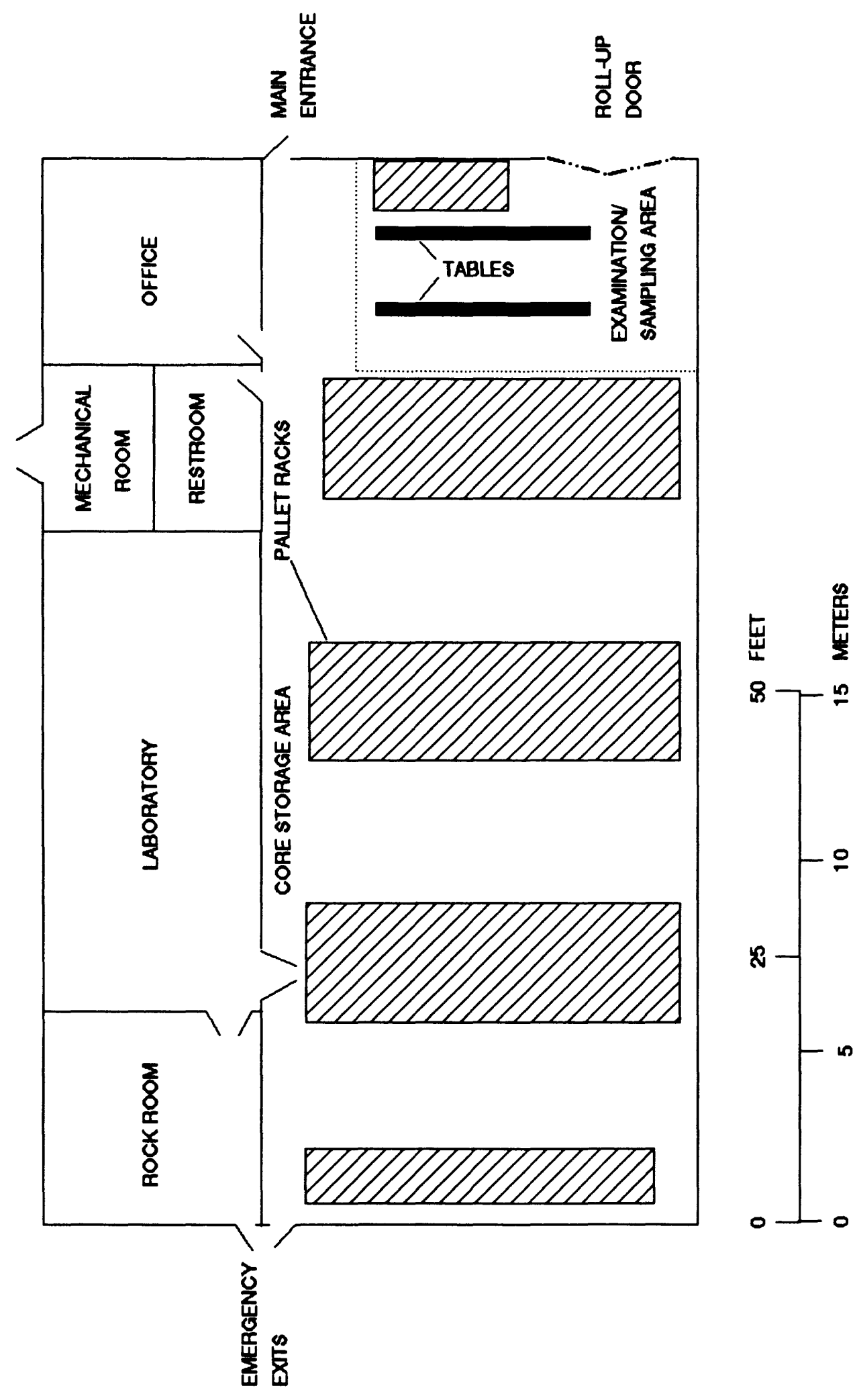

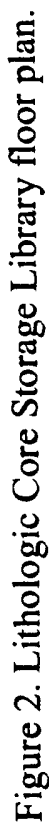


containing results of analyses performed on cores and cuttings are stored in the office area and are available for inspection.

\section{PROCEDURES FOR USE OF THE LITHOLOGIC CORE STORAGE LIBRARY}

The CSL is open to researchers who have a legitimate purpose for examining, sampling, or testing cores. The INEL and the CSL are restricted-access areas, and permission to visit must be obtained prior to arrival at the INEL. Access to the CSL is by appointment only: appointments can be made by calling the CSL curator at (208) 526-2102 or (208) 526-2438. The curator usually can arrange access with INEL security; however, special arrangements must be made for non-U.S. citizens. Detailed procedures for obtaining access to the CSL and permission to sample cores and cuttings can be found in the INEL Lithologic Core Storage Library Standard Operating Procedures, SOP No.:CSL-SOP-8.1.1, which is available for inspection at the USGS Project Office at the INEL. The CSL is open Monday through Thursday, 7:30 a.m. to 5:00 p.m.; however, arrangements for altemate days and times may be made at the discretion of the curator.

Researchers must provide the curator of the CSL with a statement of proposed research detailing the purpose and scope of the project, including a description of analyses to be performed on the samples. The minimum sample size or volume needed, and whether or not the analyses will destroy the samples, must be specified. Requests for large volumes of samples that will be destroyed, and which may deplete an interval of core or cuttings, must be justified. The curator of the CSL is responsible for obtaining approval for sampling from the owner of the cores. If additional testing of samples other than that outlined in the statement of proposed research is required, written permission from the curator of the CSL or owner of the samples must be obtained prior to testing. Researchers are encouraged to do their own sampling after approval has been granted. CSL personnel are available for assistance in operating machinery and recording samples borrowed. CSL personnel may be available to sample materials for researchers if the number of samples requested is small and arrangements are made in advance.

One copy of published reports containing results of analyses performed on materials furnished by the CSL, interpretations based on analyses, or unpublished data must be provided to the curator for inclusion in the database. CSL personnel can keep unpublished data confidential, if requested; however, because availability of data may reduce duplication of, or supplement data from other researchers, release of data is encouraged.

All borrowed samples that may be of use to other researchers must be returned to the CSL, with a description of analyses made. Portions of samples that were not used also must be returned. All samples retumed must be clearly marked with the number of the well and the depth below land surface from which they were removed. Although not required, thin sections may be donated to the CSL for archiving.

\section{DRILL CORES AND CUTTINGS AVAILABLE AT THE LITHOLOGIC CORE STORAGE LIBRARY}

Table 1 is a compilation of information about cores and cuttings stored at the CSL. All cores and cuttings are available for sampling provided permission has been obtained from the owner of the cores or cuttings by the curator of the CSL. All cores and cuttings are available for examination without permission of the owner. Data for table 1 were compiled from many sources, including Anderson and others (1996), Bartholomay (1990), Sehlke and others (1994), verbal communications with contractors, well completion reports and diagrams, and other documentation. Because some of the data could not be verified by the authors, or is incomplete, the reader is encouraged to contact the curator with corrections or additional data that could improve table 1. Cores and cuttings for which the locations were not found may still be valuable for tests in which location is unimportant. 
Latitude and longitude were determined from maps, traditional land surveying techniques, or using the global positioning system. In this report, latitude and longitude are referenced to the North American Datum of 1927. Data supplied to the CSL in the form of northing and easting coordinates of the Idaho State Planar Coordinate System were converted to latitude and longitude using CORPSCON, 1991, version 2.1, a datum transformation program developed by the U.S. Army Engineer Topographic Laboratories.

\section{SUMMARY}

The INEL Lithologic Core Storage Library (CSL), located in Building CFA-663, Central Facilities Area, was established in 1990 to consolidate, catalog, and permanently store nonradioactive drill cores and cuttings, mostly from the INEL subsurface, in one location. Before establishment of the CSL, cores and cuttings were stored in many locations and were not easily accessible to researchers for use. As of 1996, personnel at the CSL had identified and cataloged about $50,000 \mathrm{ft}$ of drill core and cuttings which are available for examination, sampling, and testing by appointment. Some petrographic thin sections also are available for examination. In this report, drill cores and cuttings are identified by INEL facility name or geographic location of the well, well name, depth intervals of cores and cuttings, latitude and longitude, Idaho county, and USGS quadrangle map. A description of the CSL, equipment available for use by researchers, procedures for access, examination, and sampling and return of materials are presented.

\section{REFERENCES CITED}

Anderson, S.R., Ackerman, D.J., Liszewski, M.J., and Freiburger, R.M., 1996, Stratigraphic data for wells at and near the Idaho National Engineering Laboratory, Idaho: U.S. Geological Survey Open-File Report 96-248 (DOE/ID-22127), 27 p., and diskette.

Bartholomay, R.C., 1990, Digitized geophysical logs for selected wells on or near the Idaho National Engineering Laboratory, Idaho: U.S. Geological Survey Open-File Report 90-366 (DOE/ID-22088), 337 p.

Sehlke, G., Davis, D.E., Smith, P.J., Jaacks, J.J., and Williams, S.J., 1994, Comprehensive well survey for the Idaho National Engineering Laboratory, DOE/ID-10402, revision 3, pp. 4-1-4-30. 


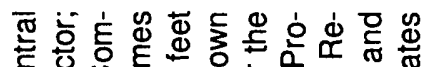
O웡

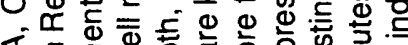
造

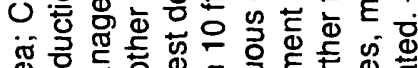

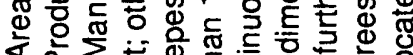

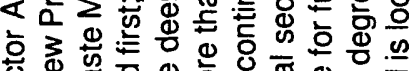

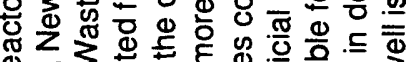

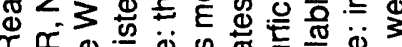

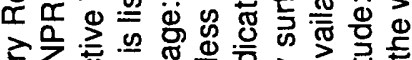
준

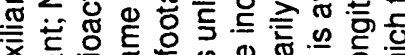

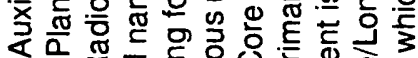
《橫

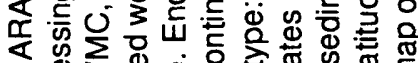
d 45 उ을 줄

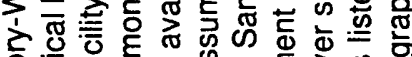

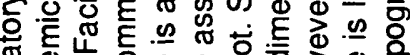
匹ั

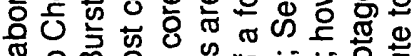
త్ 元

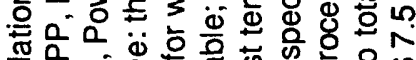

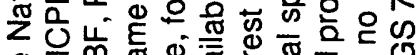

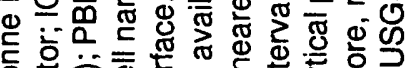

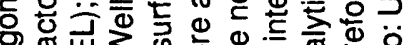

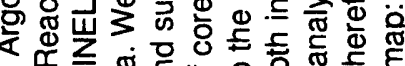
3웡

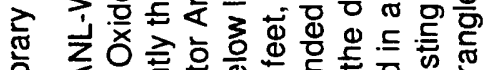

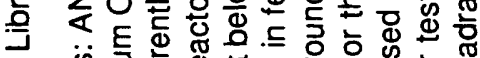
讪

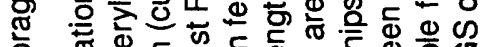
क

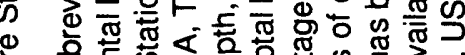
ठั

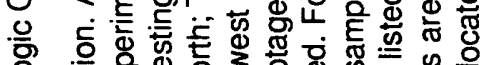
잉

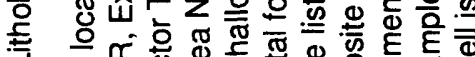

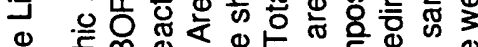

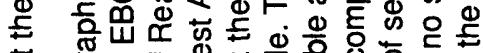

(1) 。 한다의

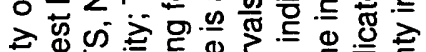

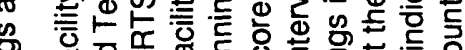

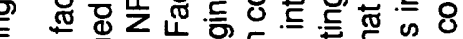
表

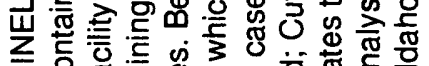

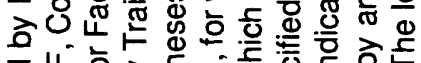
崖咅记

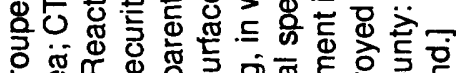

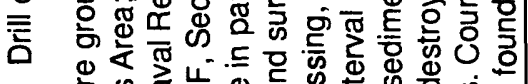

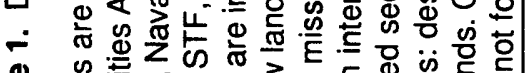

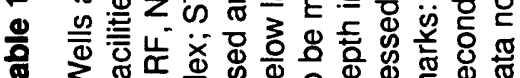

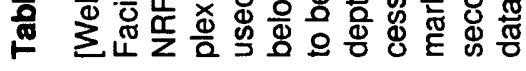

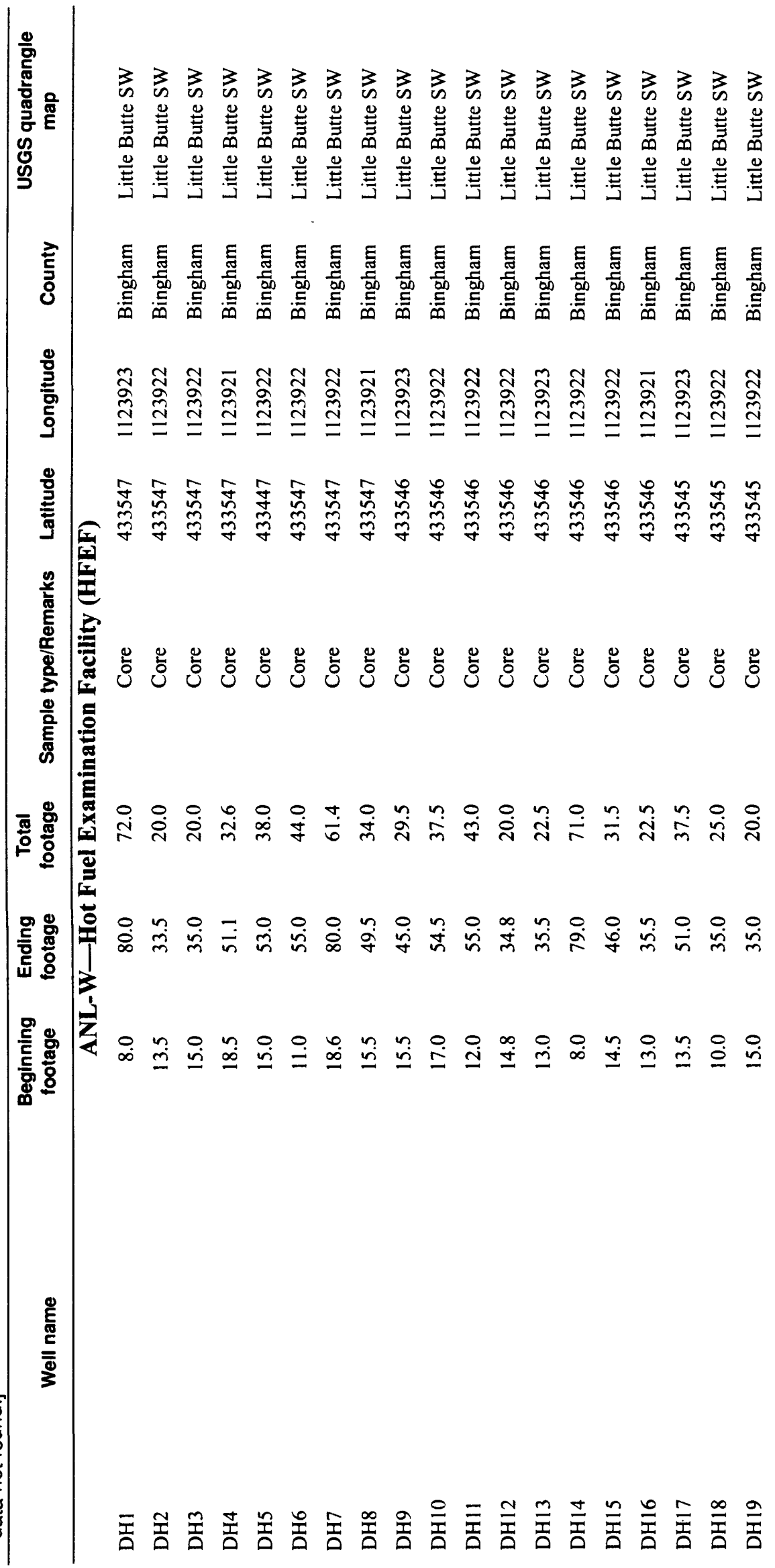




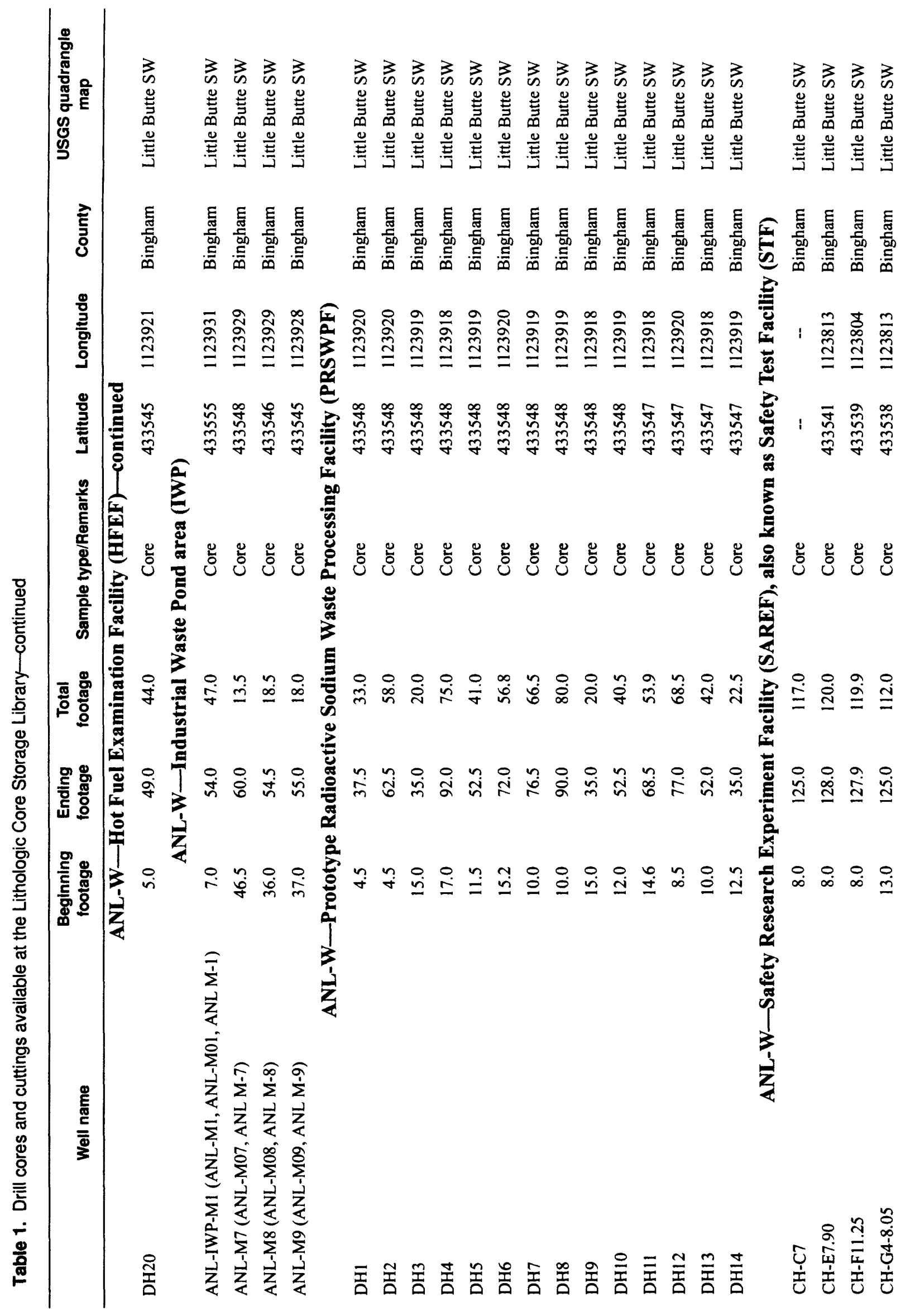




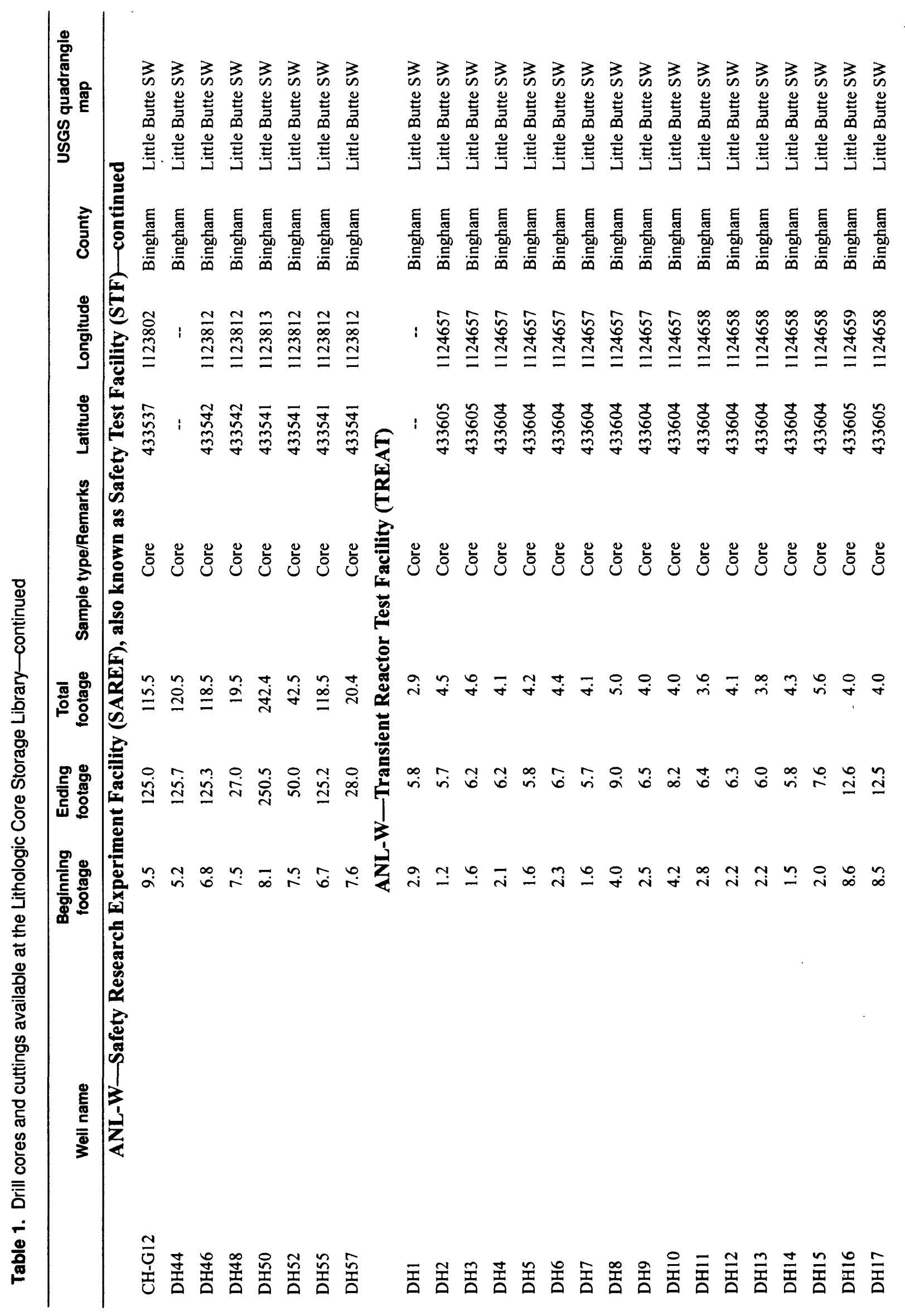




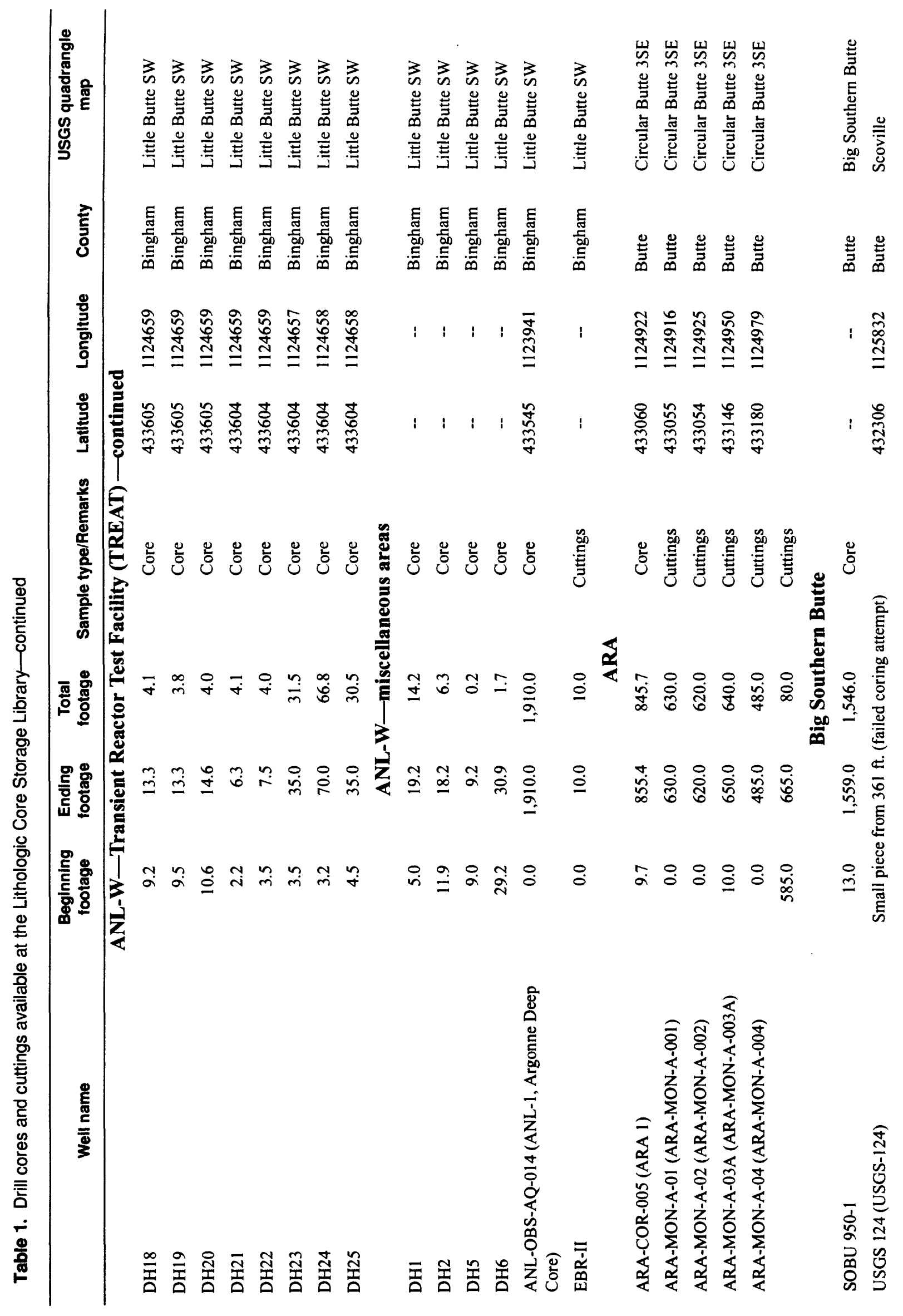




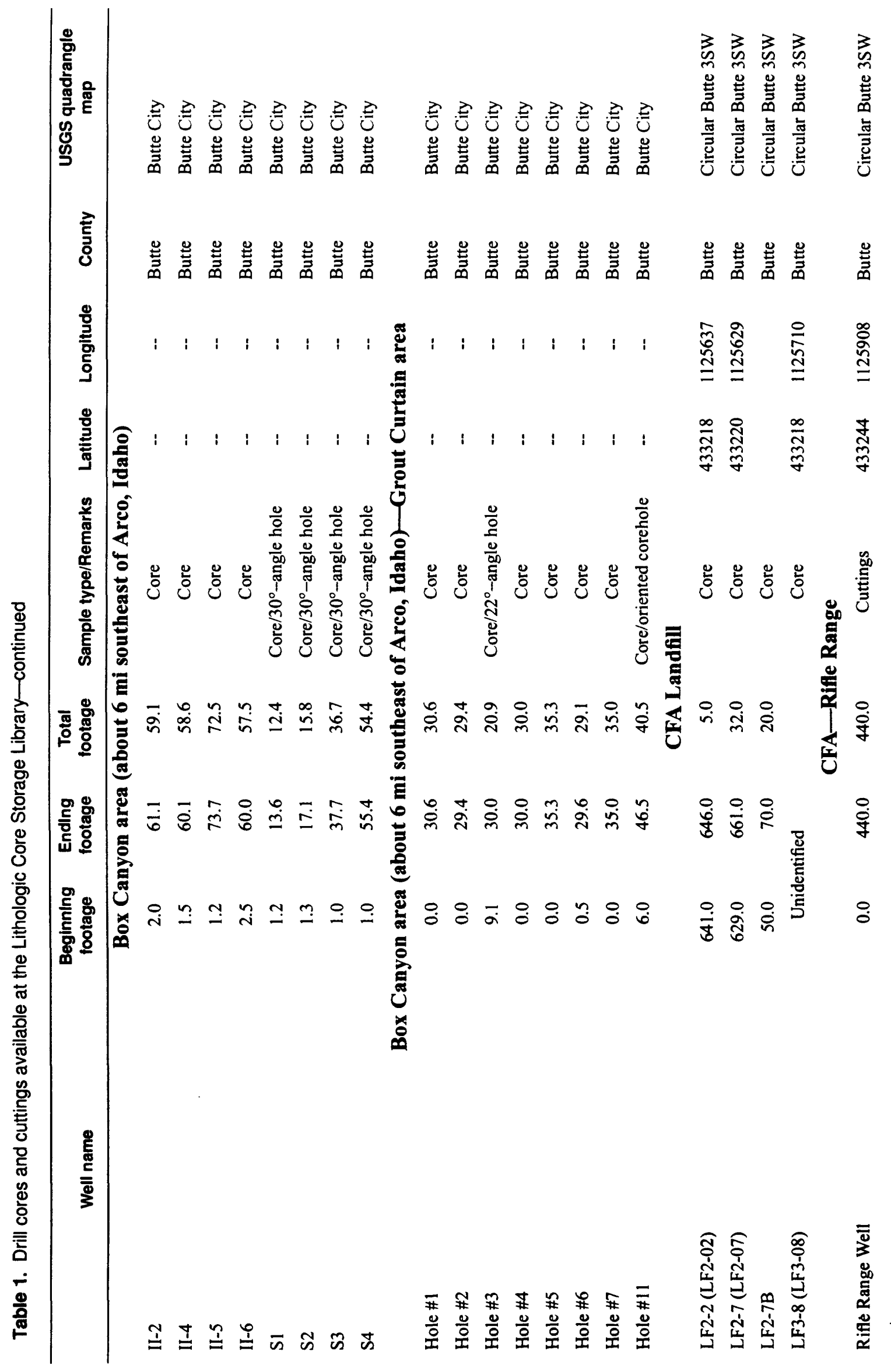




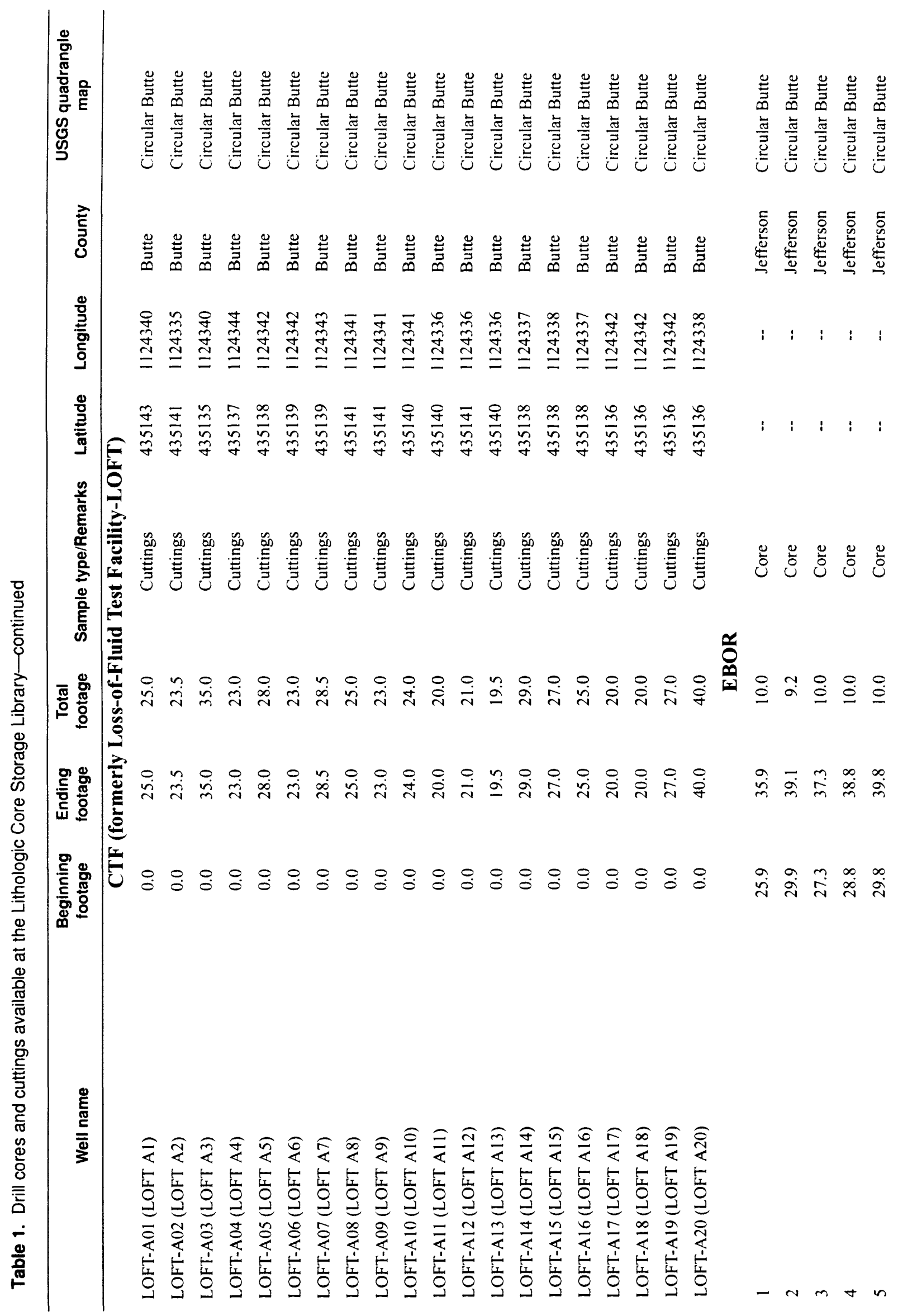




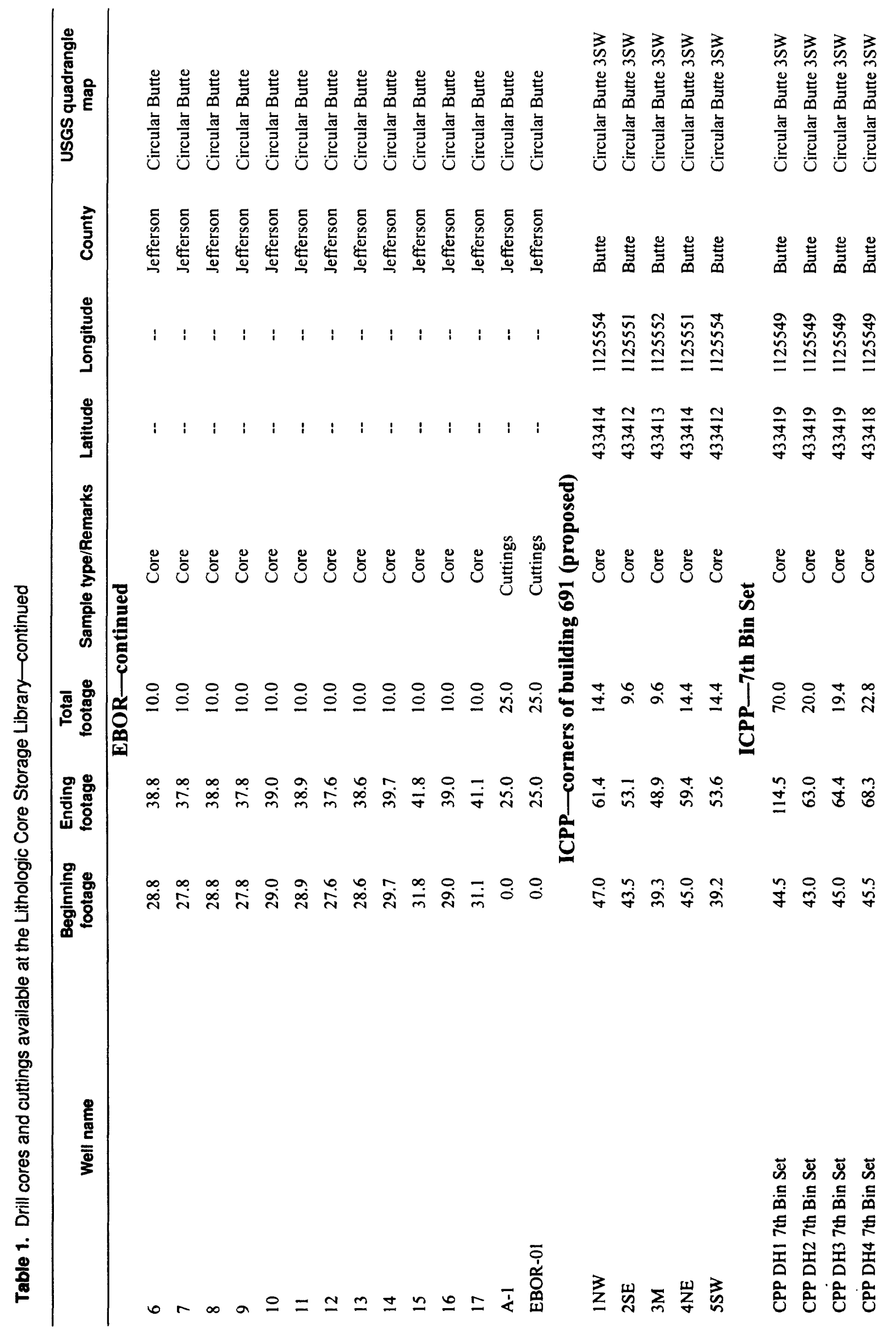




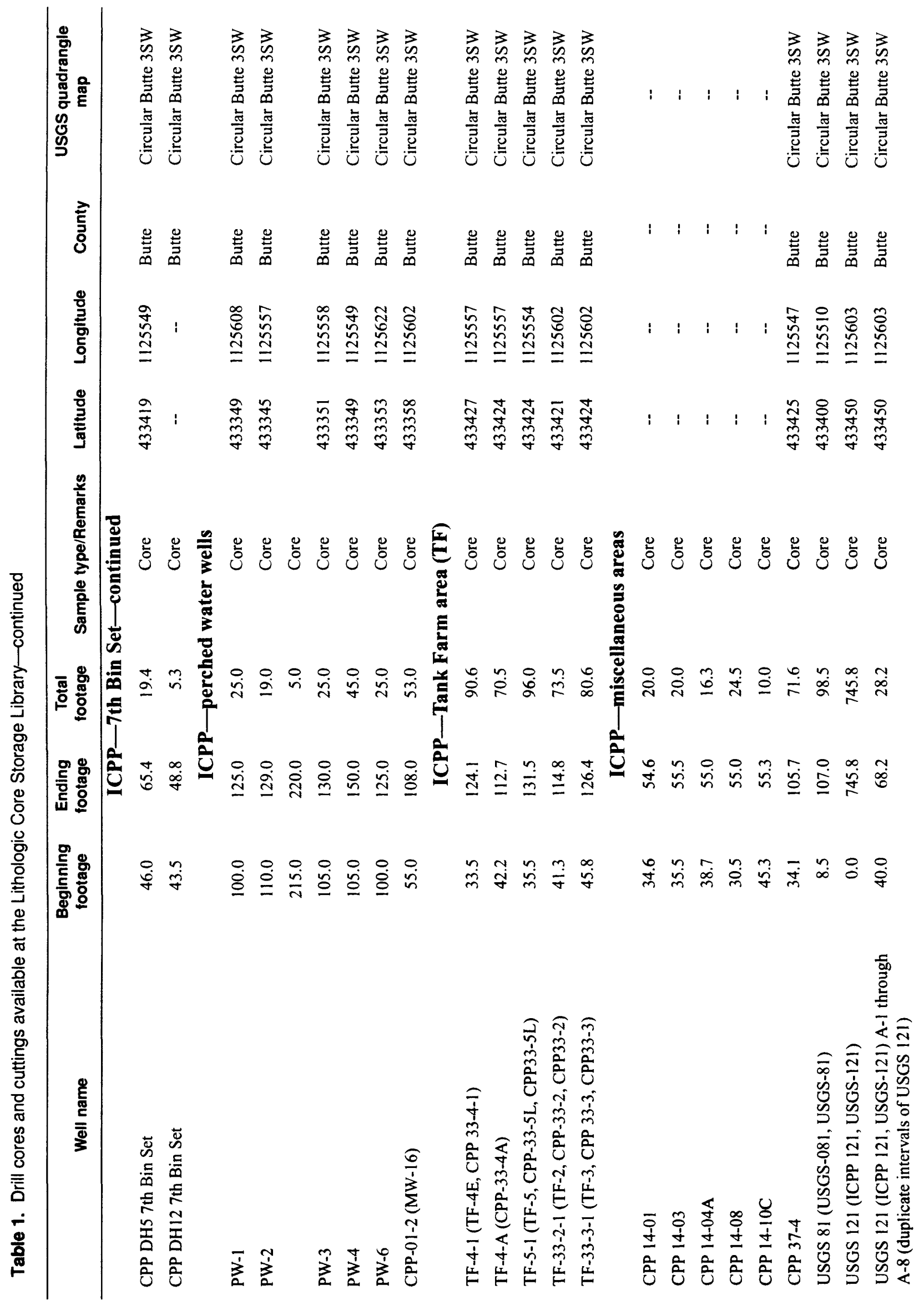




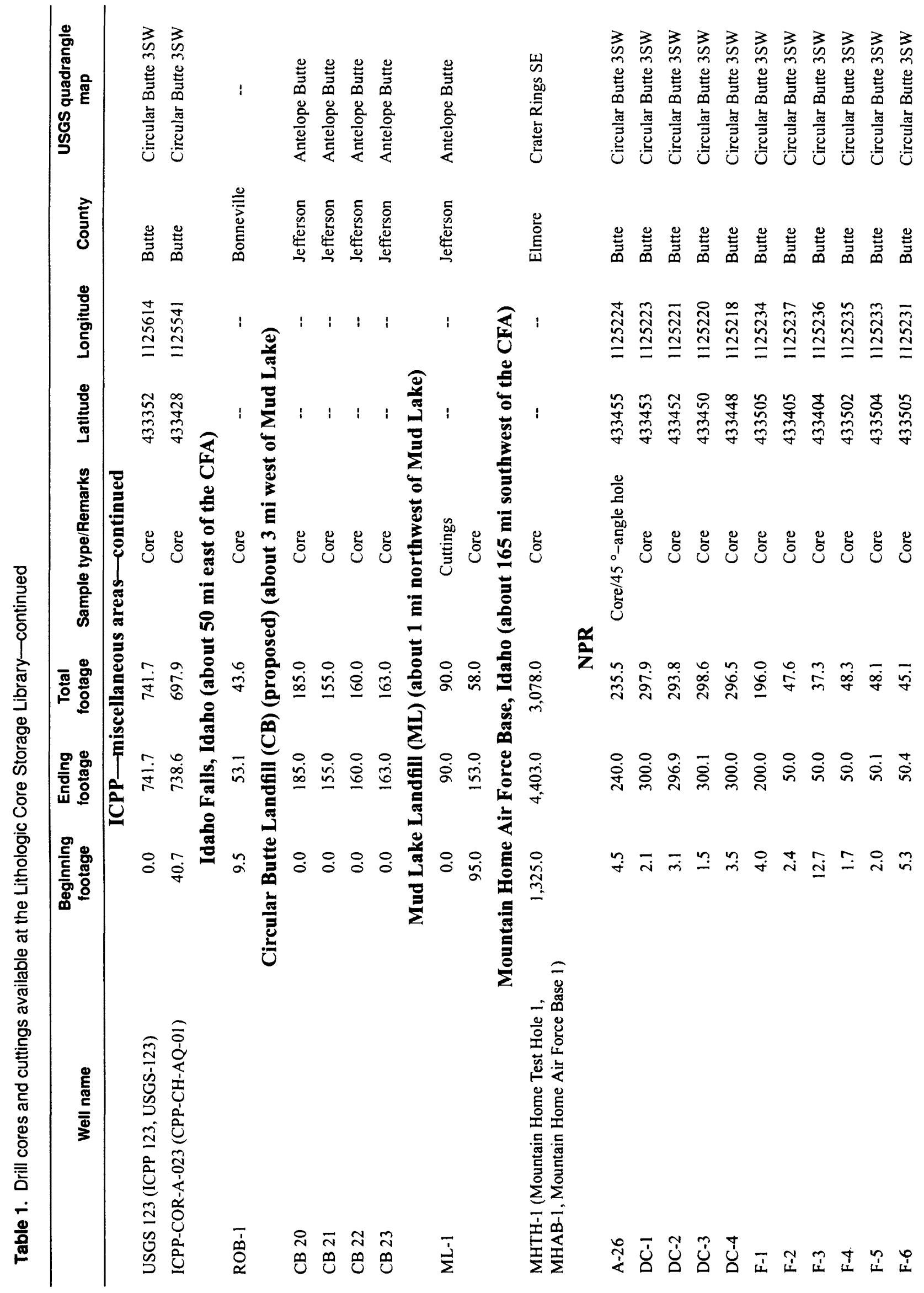




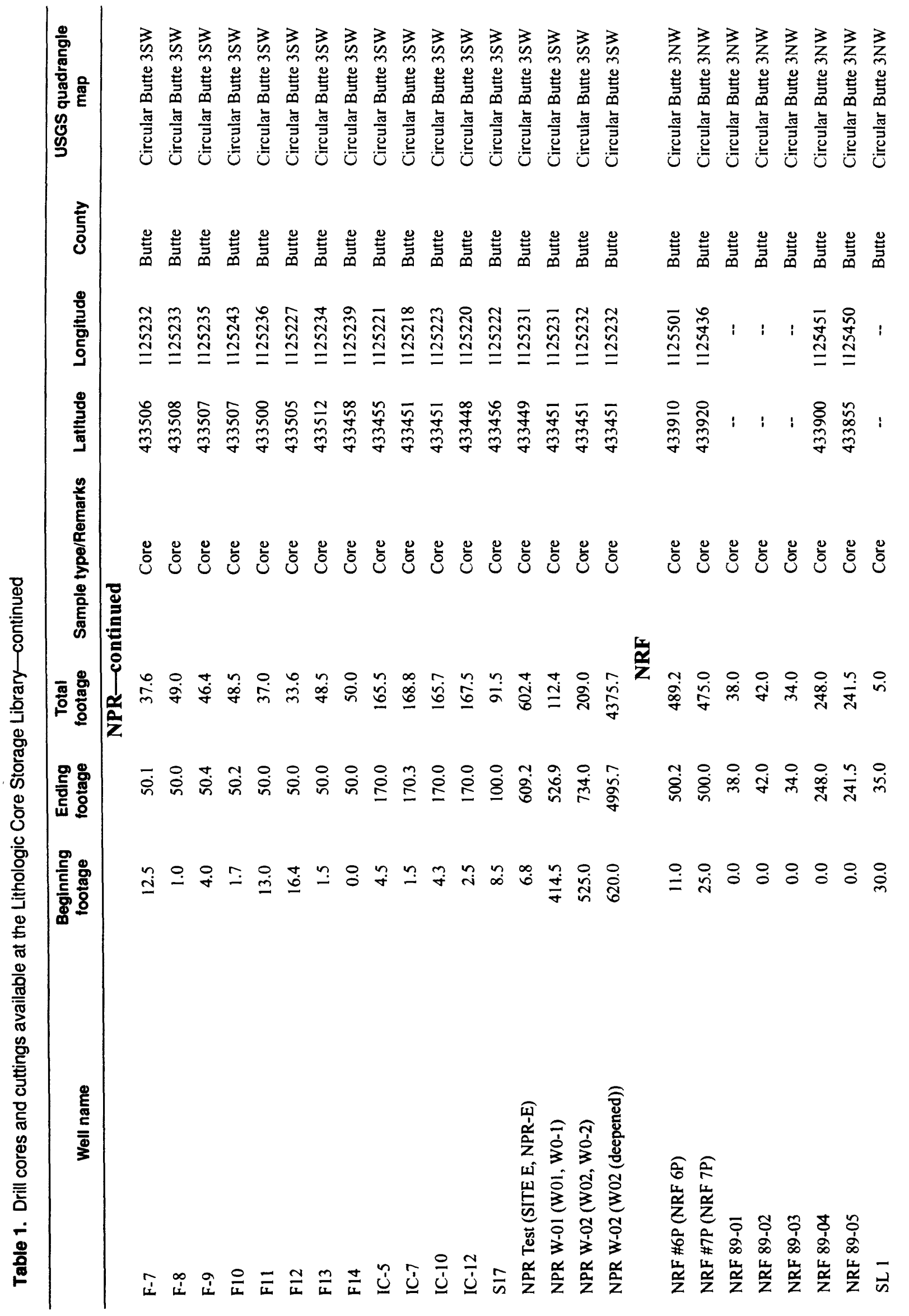




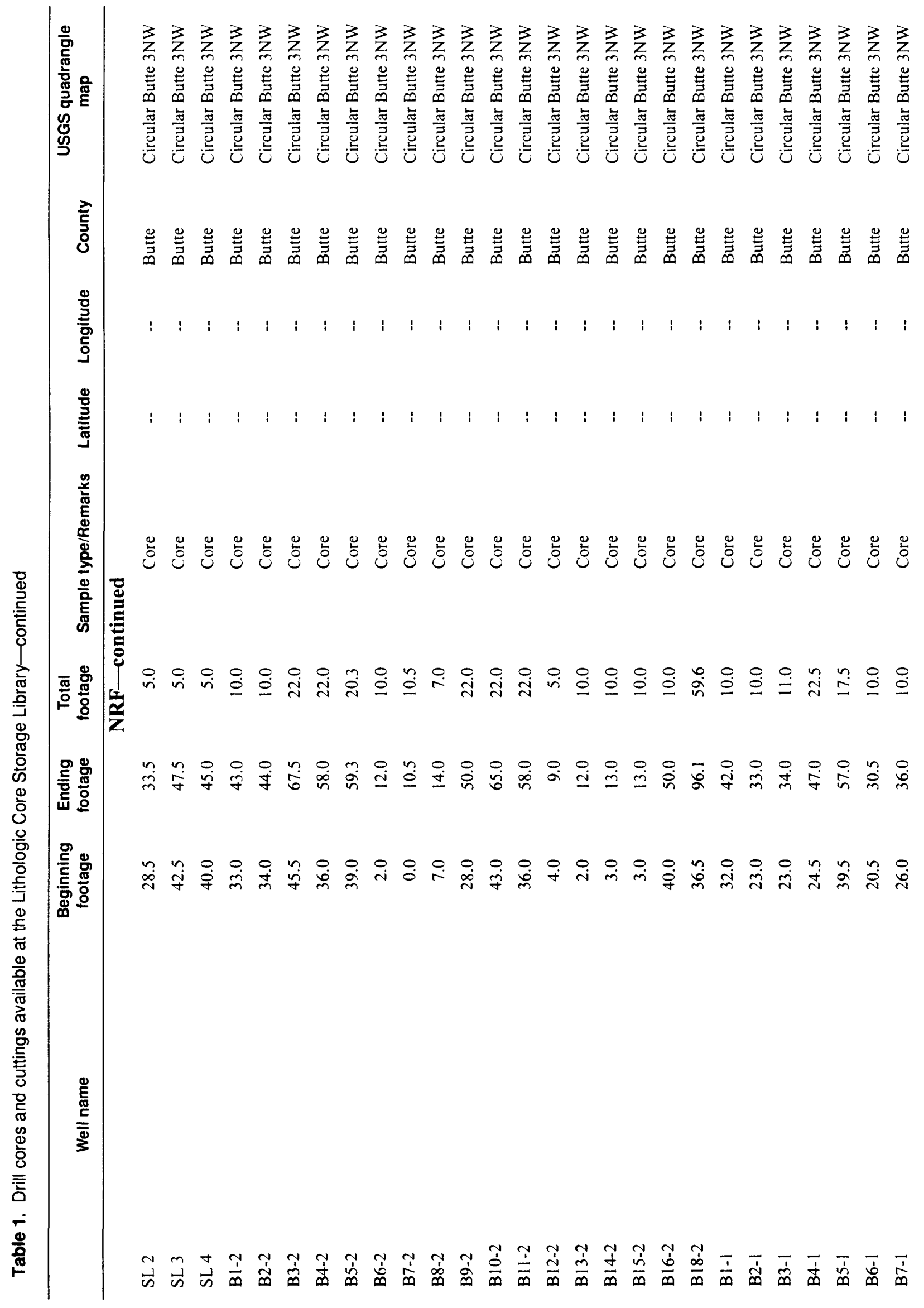




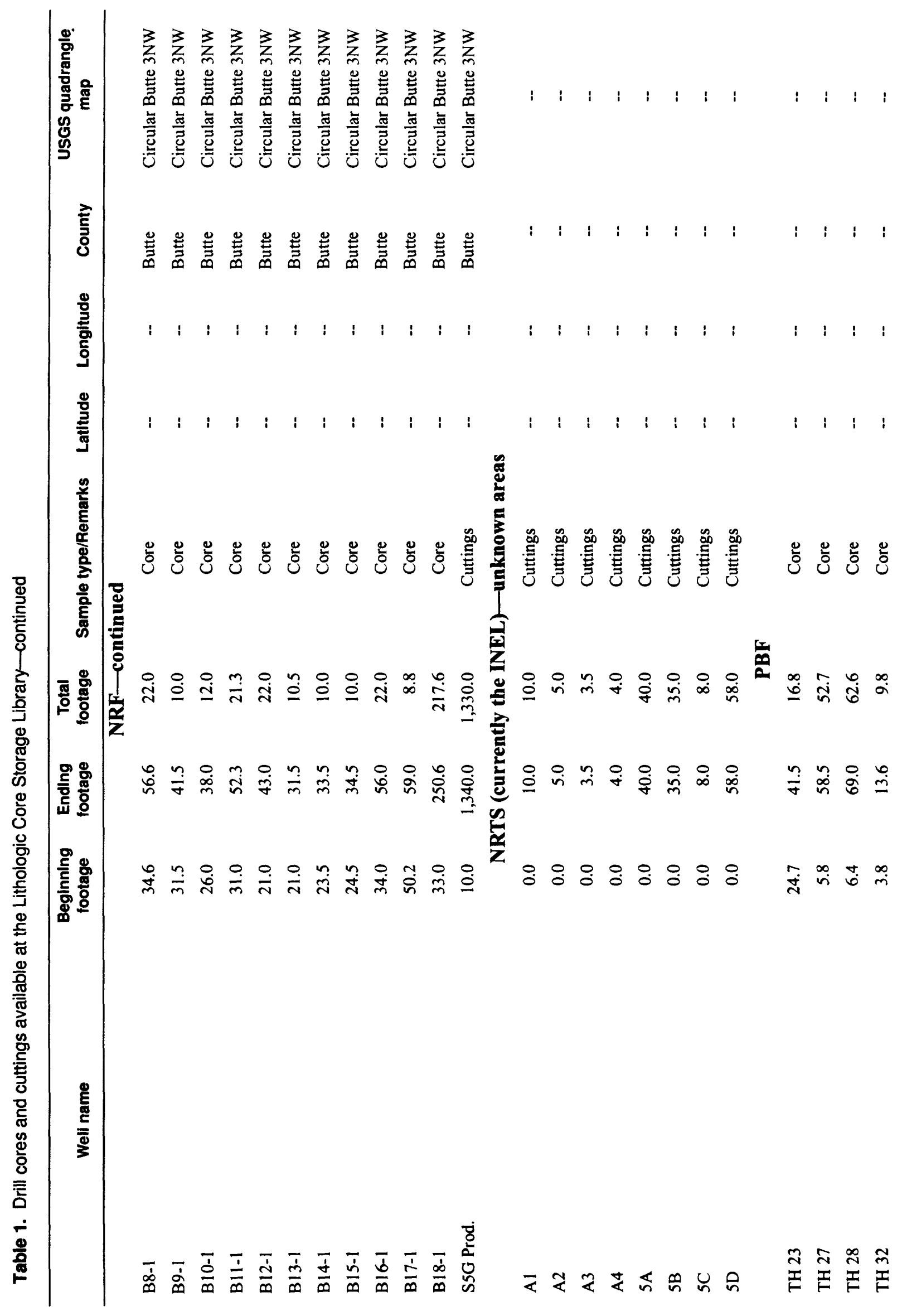




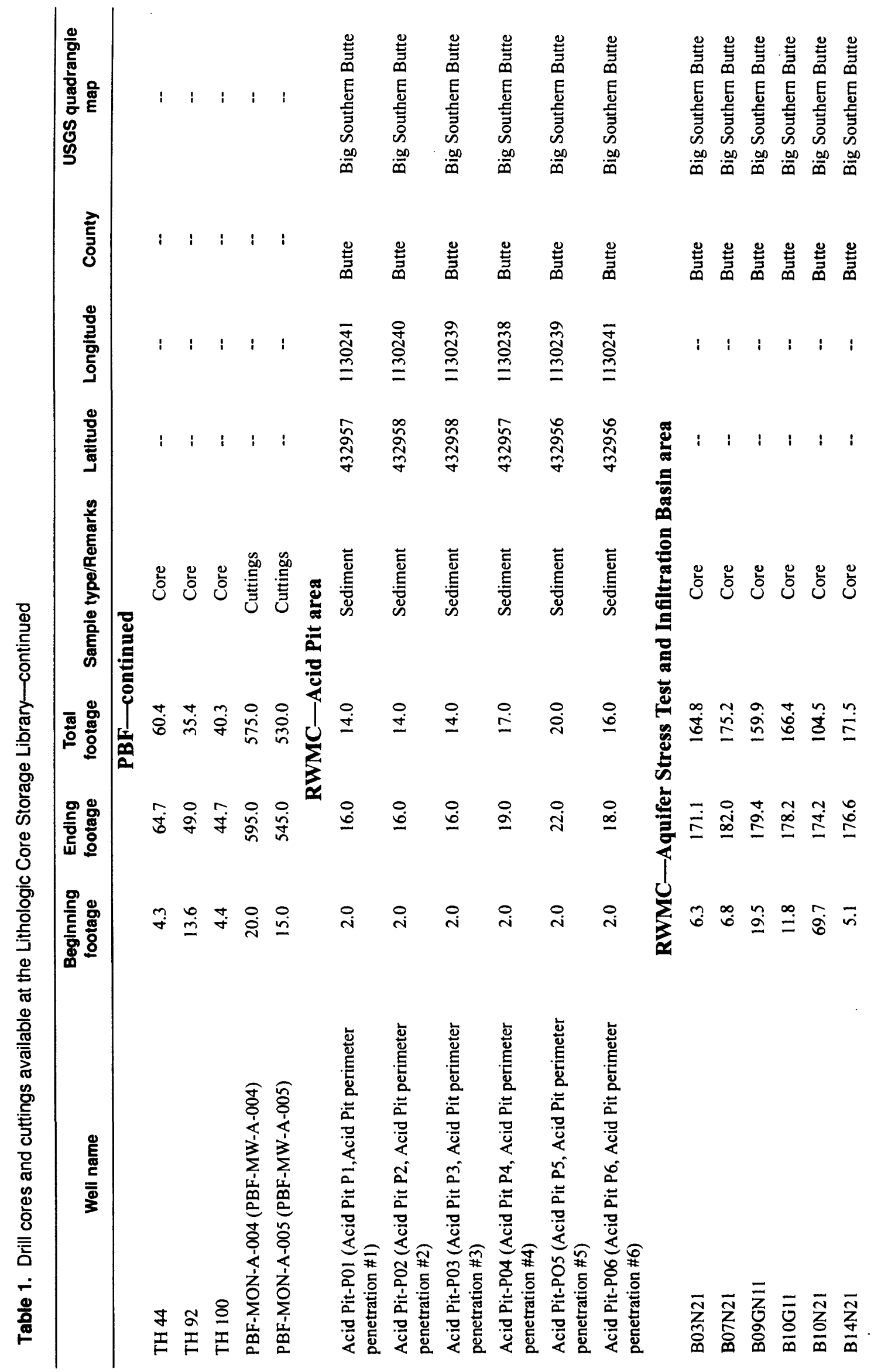




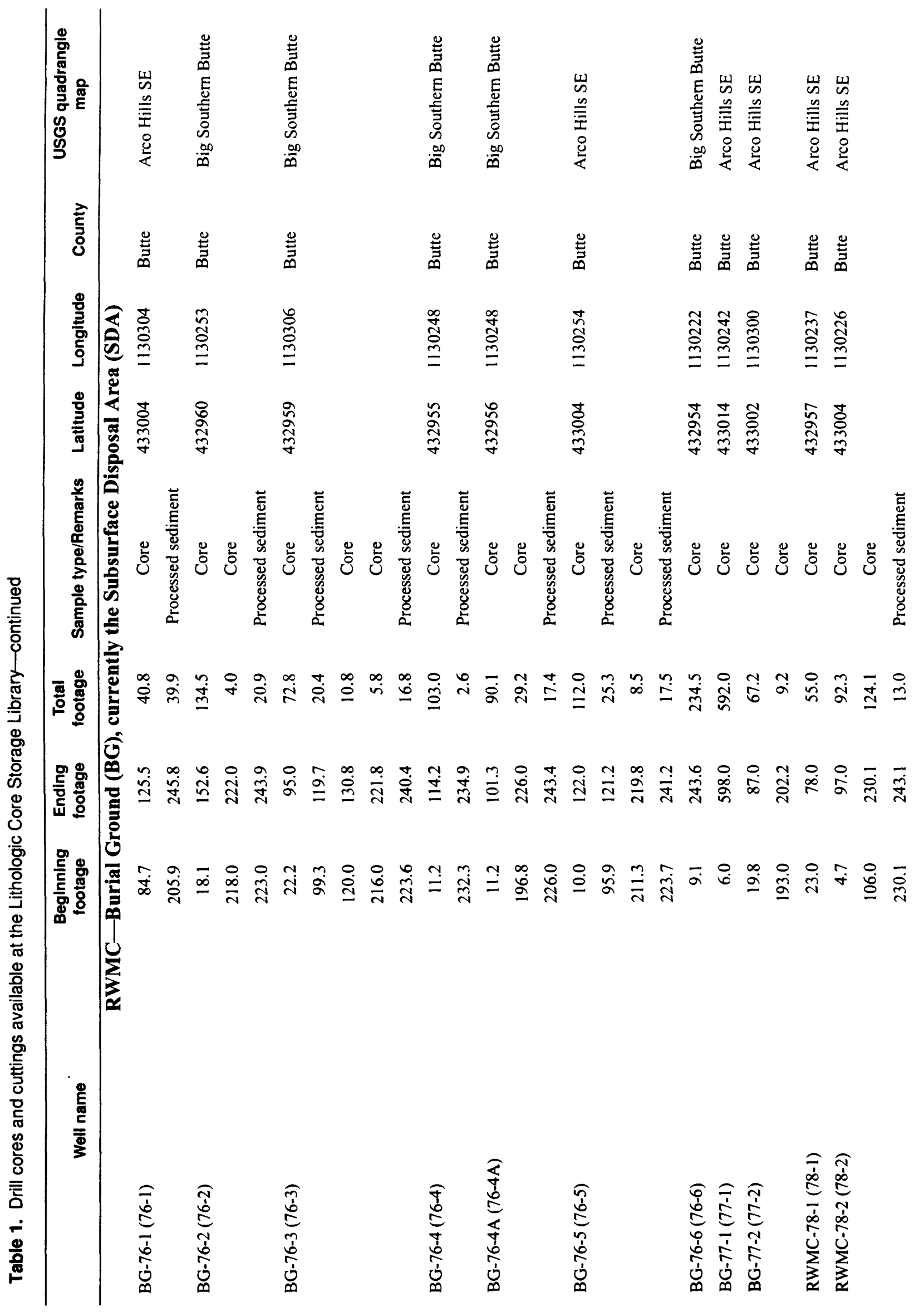




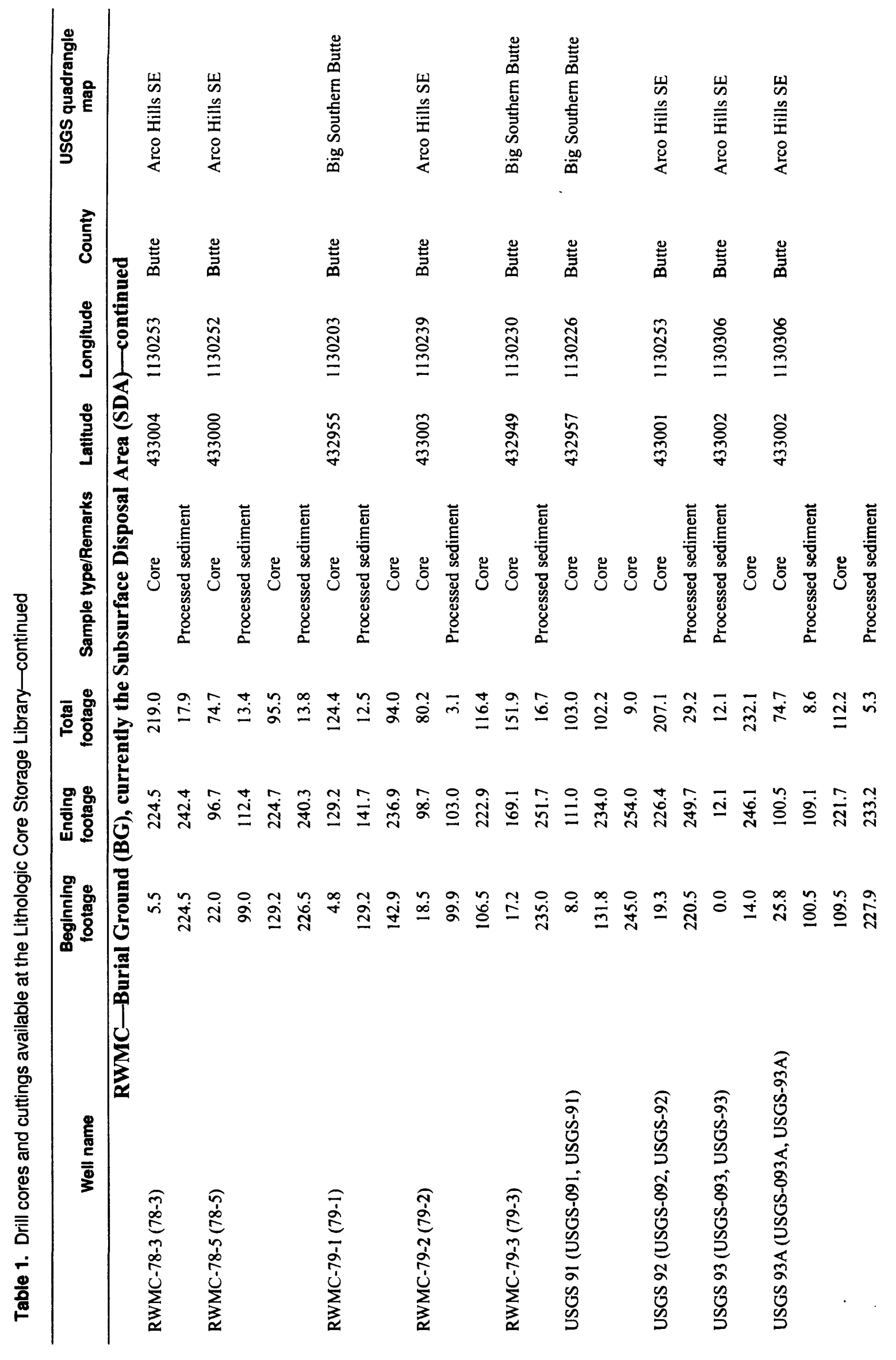




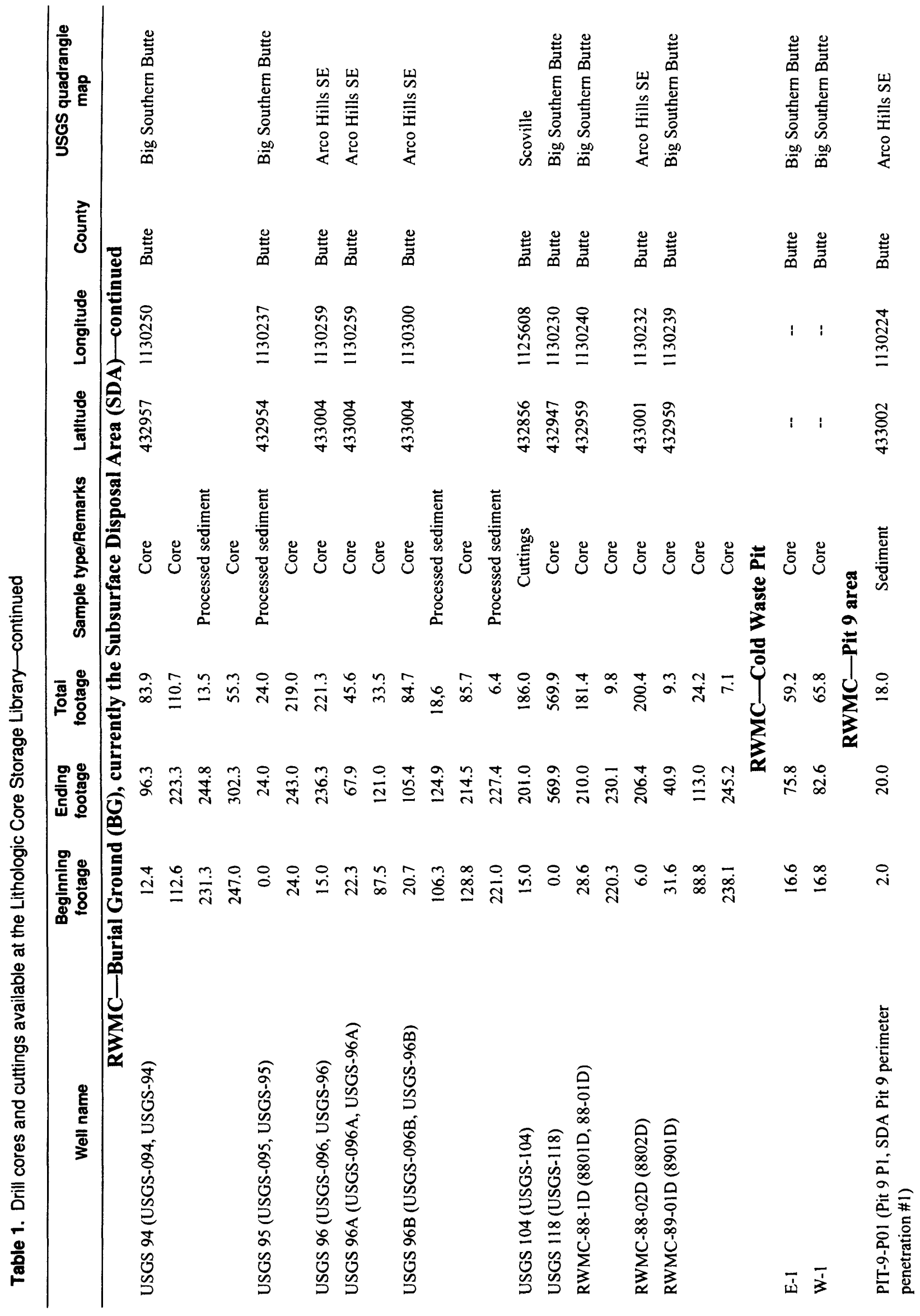




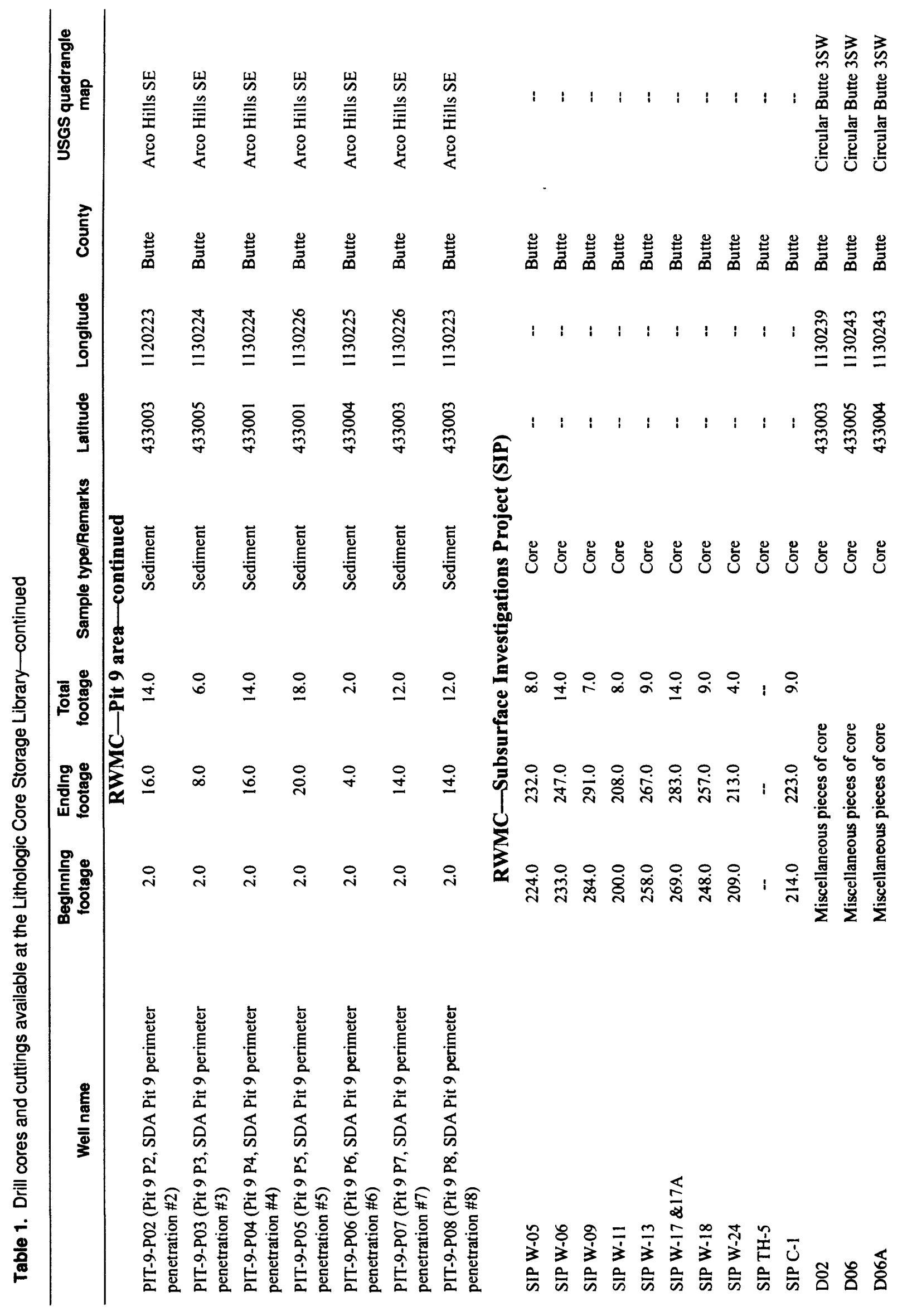




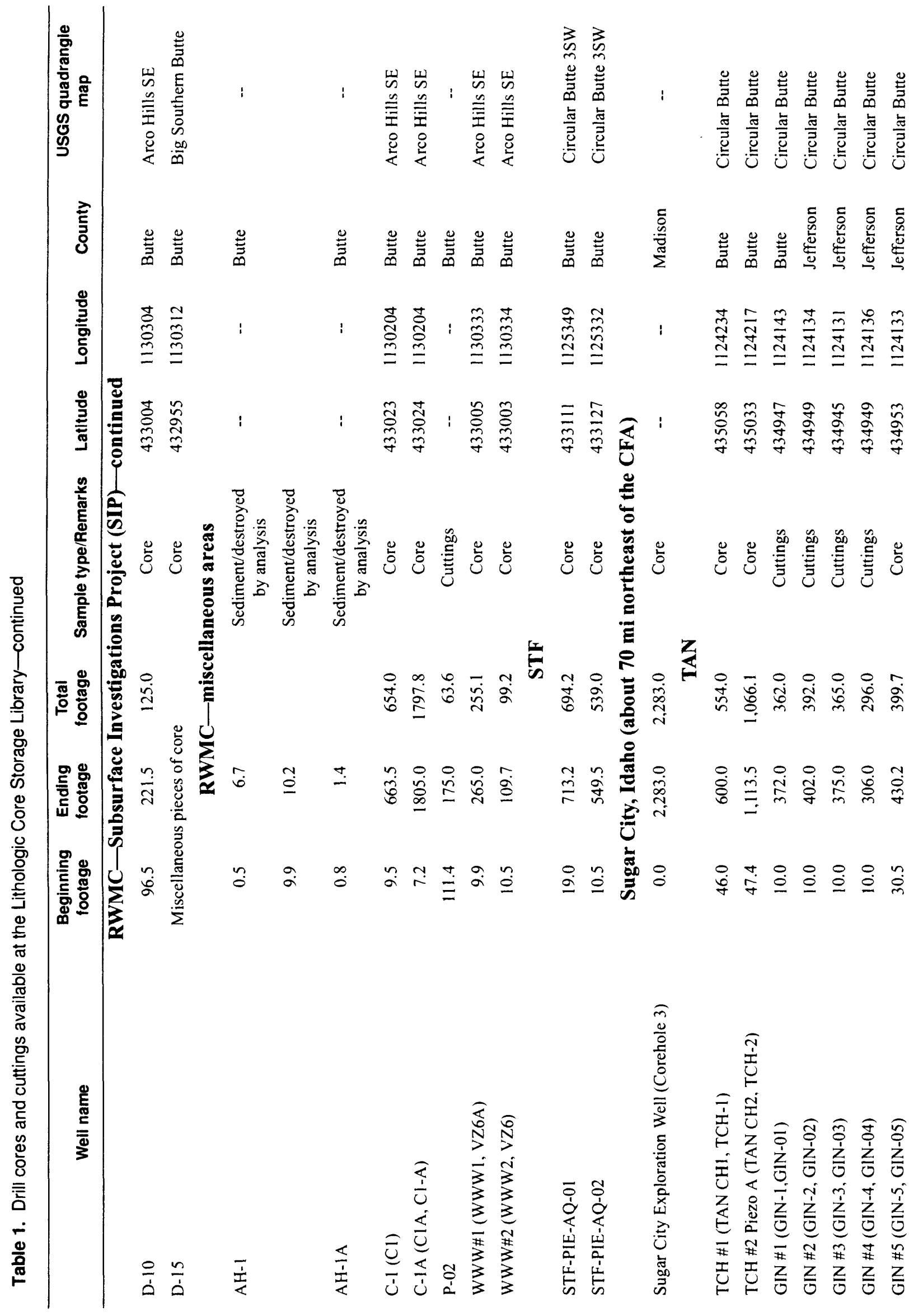




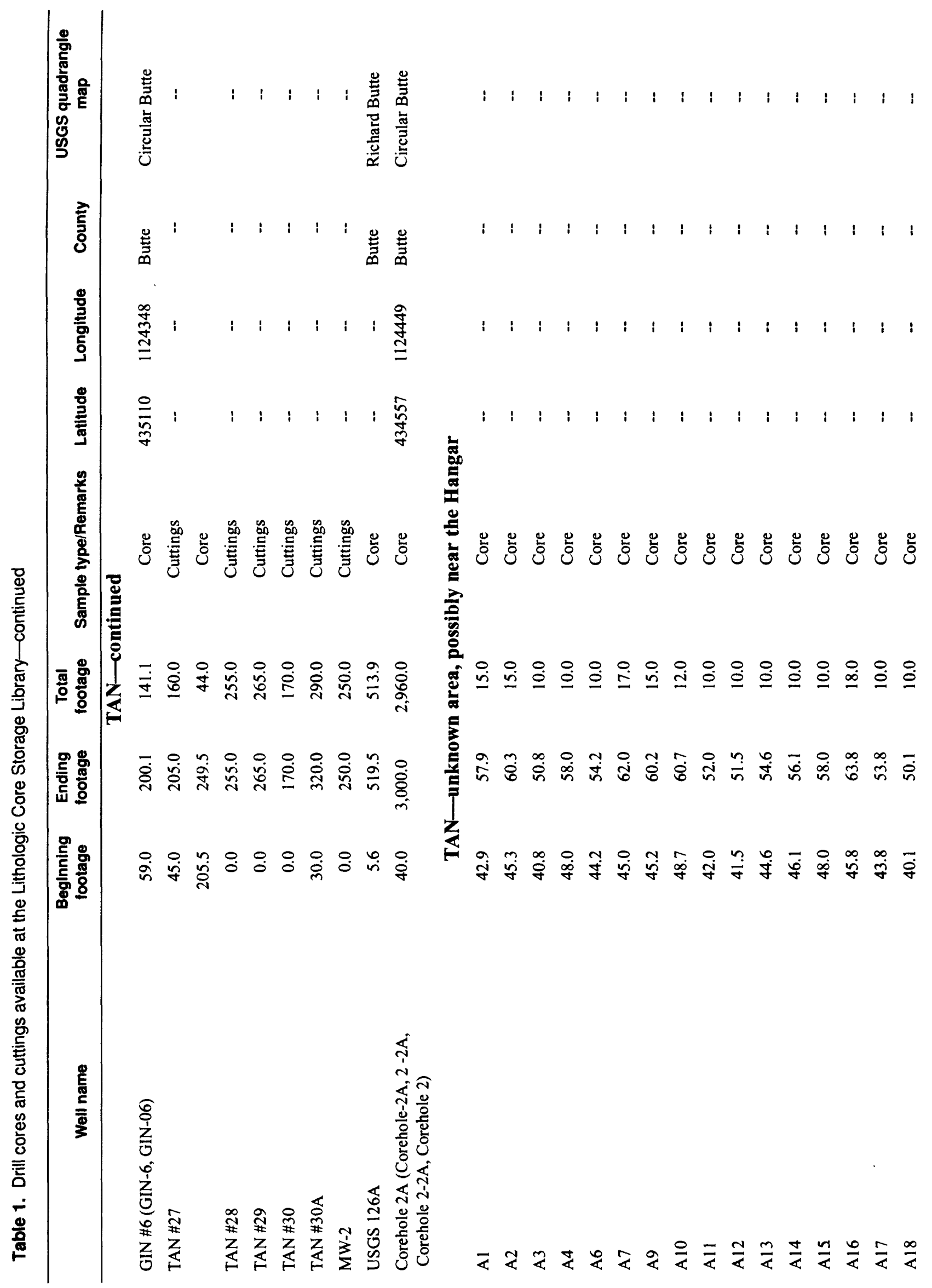




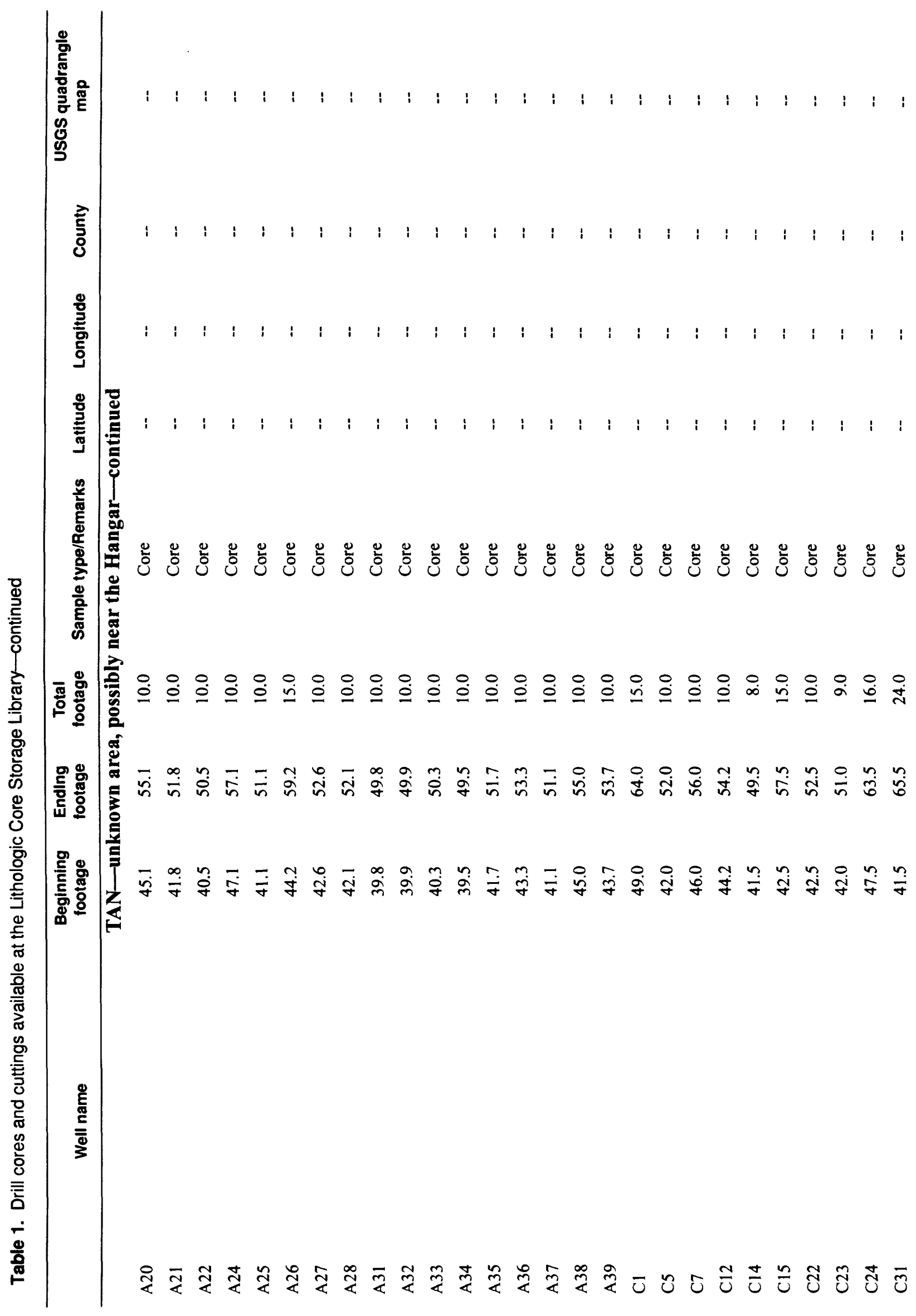




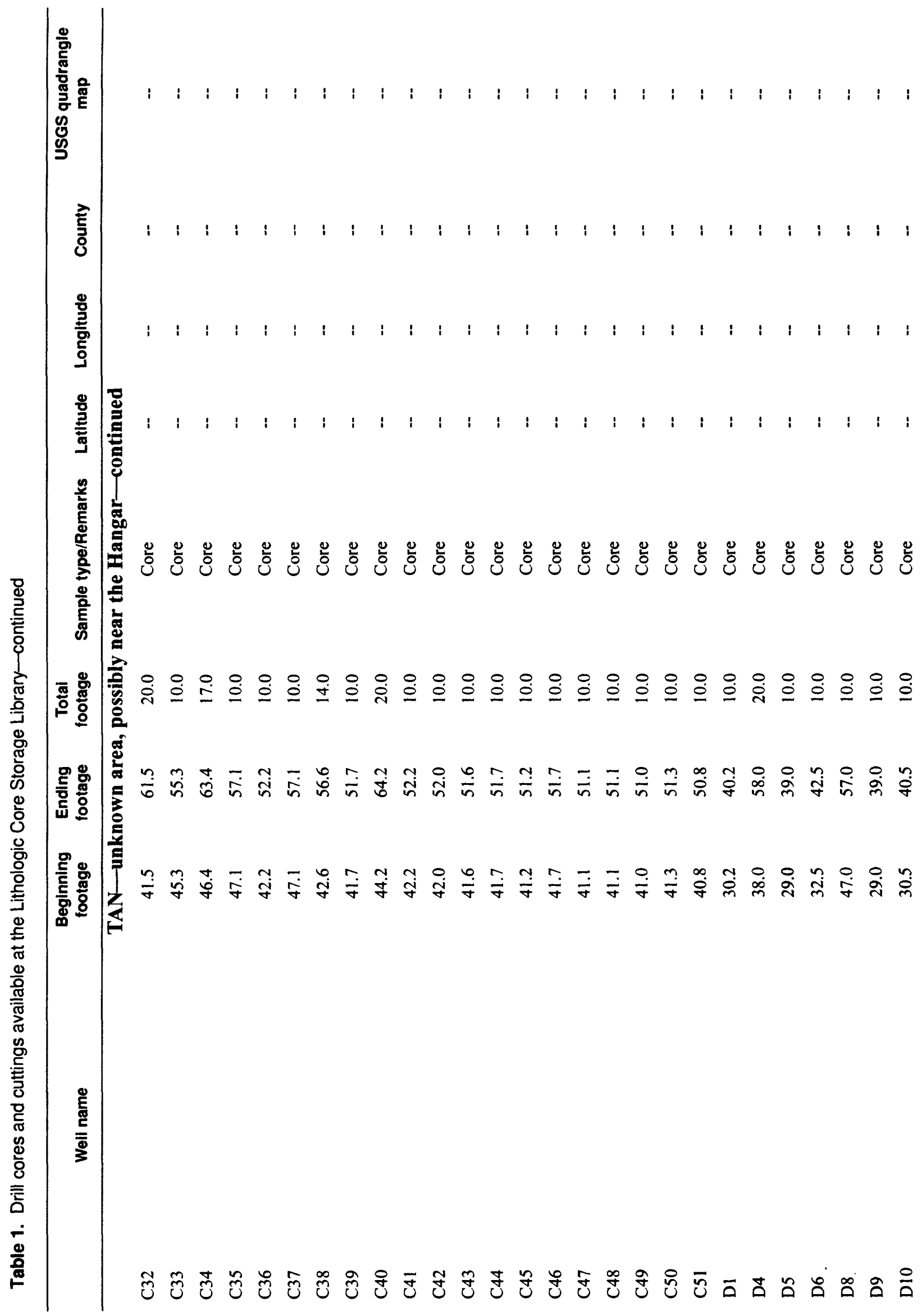




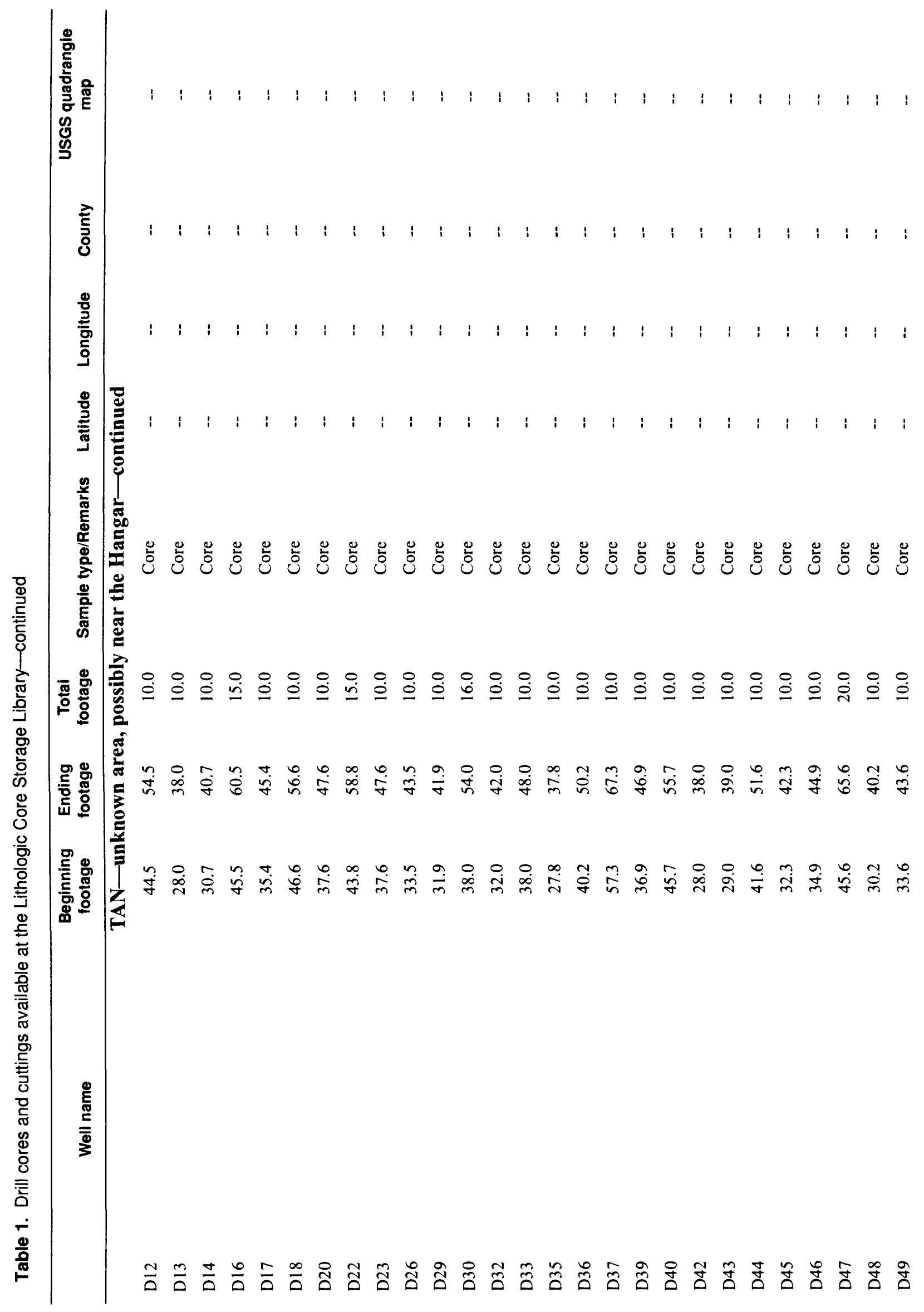




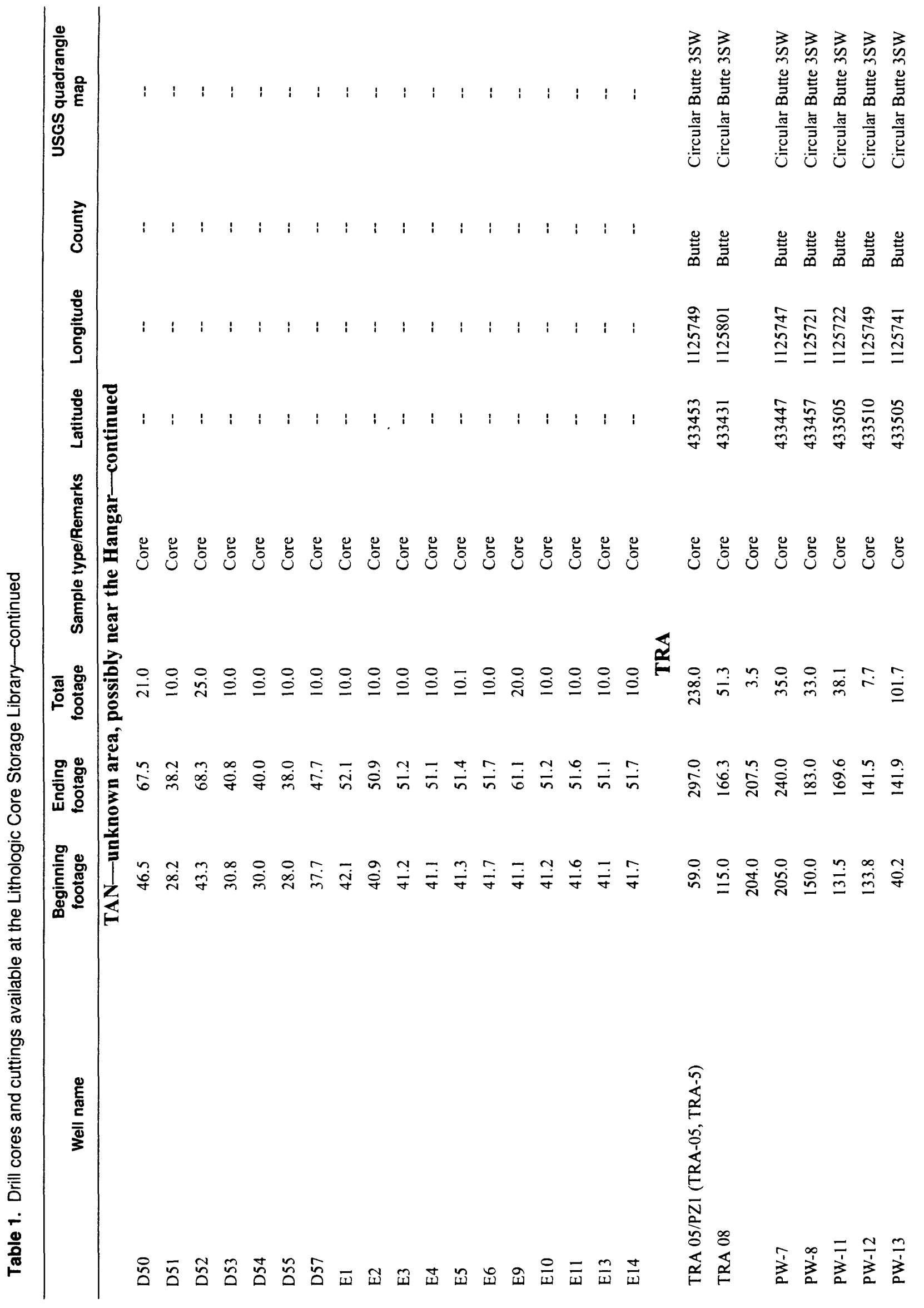




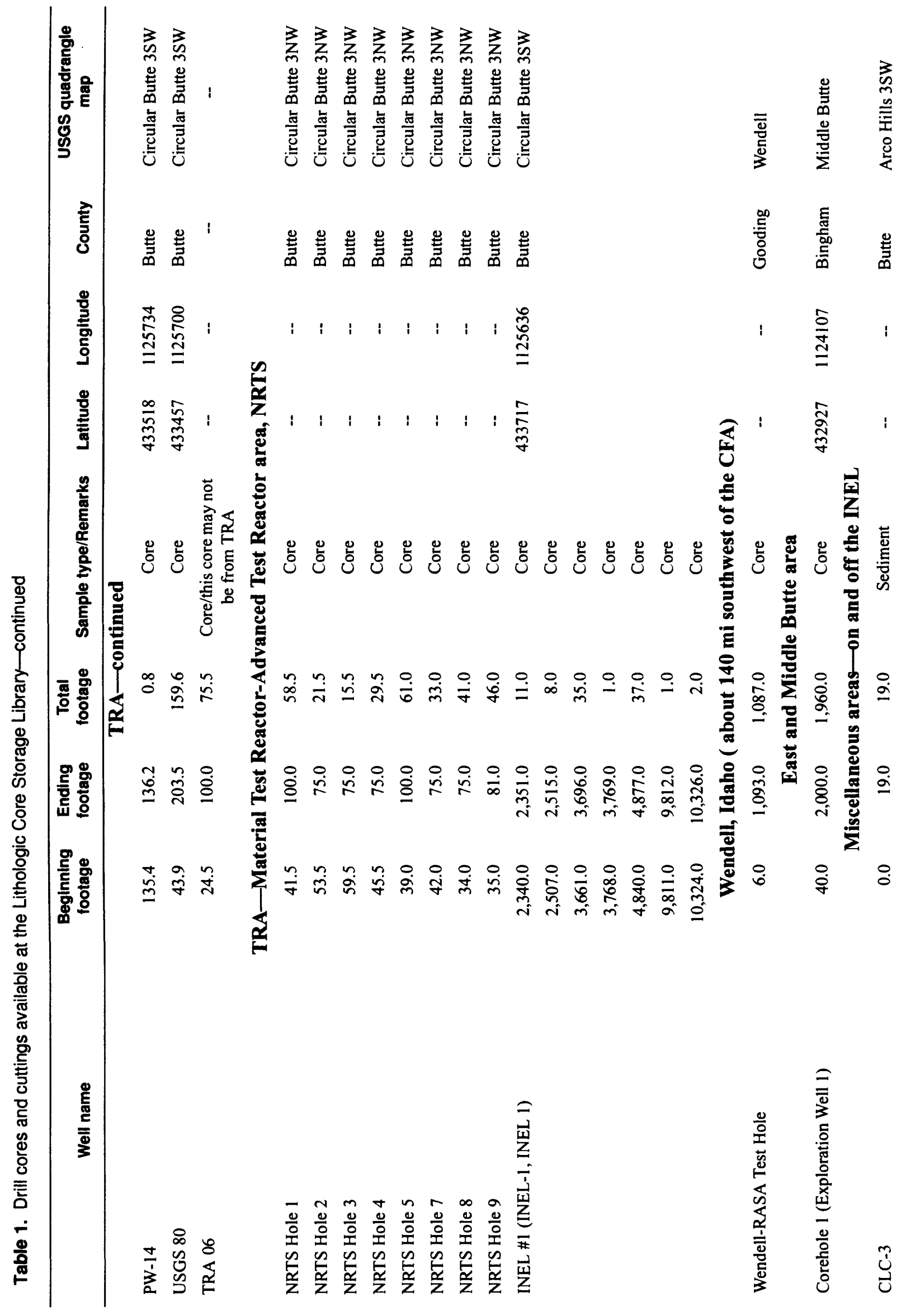




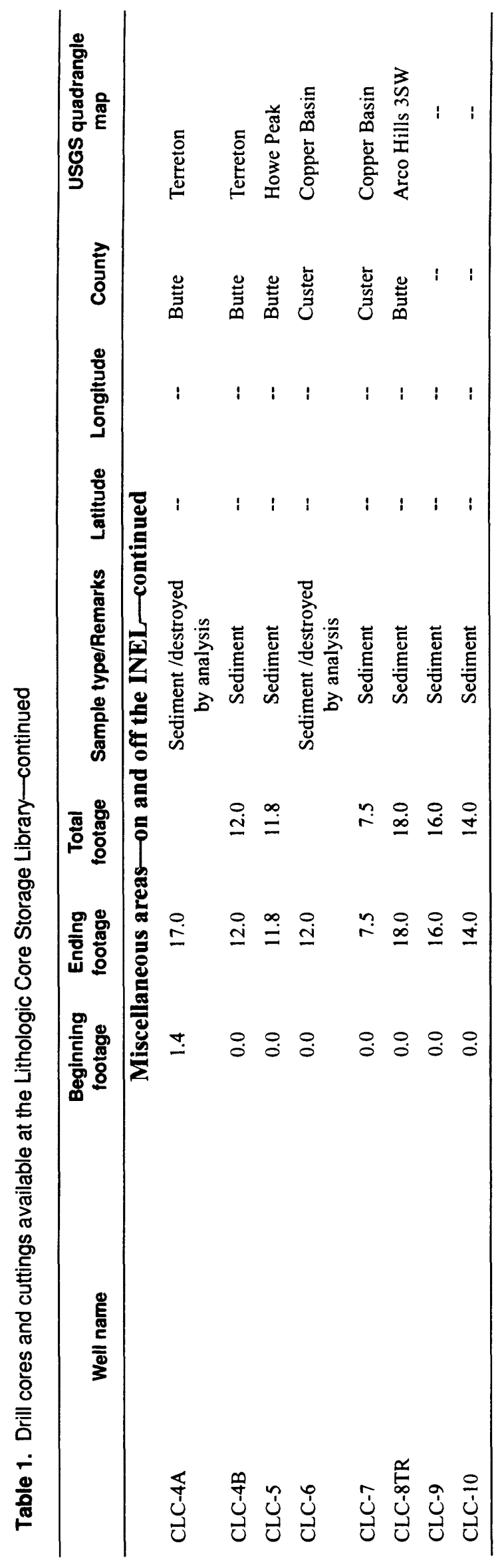

